\title{
Tropospheric ozone changes, radiative forcing and attribution to emissions in the Atmospheric Chemistry and Climate Model Intercomparison Project (ACCMIP)
}

D. S. Stevenson ${ }^{1}$, P. J. Young ${ }^{2,3, *}$, V. Naik ${ }^{4}$, J.-F. Lamarque ${ }^{5}$, D. T. Shindell ${ }^{6}$, A. Voulgarakis ${ }^{7}$, R. B. Skeie ${ }^{8}$, S. B. Dalsoren ${ }^{8}$, G. Myhre ${ }^{8}$, T. K. Berntsen ${ }^{8}$, G. A. Folberth ${ }^{9}$, S. T. Rumbold ${ }^{9}$, W. J. Collins ${ }^{9}$,**, I. A. MacKenzie ${ }^{1}$, R. M. Doherty ${ }^{1}$, G. Zeng ${ }^{10}$, T. P. C. van Noije ${ }^{11}$, A. Strunk ${ }^{11}$, D. Bergmann ${ }^{12}$, P. Cameron-Smith ${ }^{12}$, D. A. Plummer ${ }^{13}$, S. A. Strode ${ }^{14,15}$, L. Horowitz ${ }^{16}$, Y. H. Lee ${ }^{6}$, S. Szopa ${ }^{17}$, K. Sudo ${ }^{18}$, T. Nagashima ${ }^{19}$, B. Josse ${ }^{20}$, I. Cionni ${ }^{21}$, M. Righi ${ }^{22}$, V. Eyring ${ }^{22}$, A. Conley ${ }^{5}$, K. W. Bowman ${ }^{23}$, O. Wild ${ }^{24}$, and A. Archibald ${ }^{25}$

${ }^{1}$ School of GeoSciences, The University of Edinburgh, Edinburgh, UK

${ }^{2}$ Chemical Sciences Division, NOAA Earth System Research Laboratory, Boulder, Colorado, USA

${ }^{3}$ Cooperative Institute for Research in Environmental Sciences, University of Colorado, Boulder, Colorado, USA

${ }^{4}$ UCAR/NOAA Geophysical Fluid Dynamics Laboratory, Princeton, New Jersey, USA

${ }^{5}$ National Center for Atmospheric Research, Boulder, Colorado, USA

${ }^{6}$ NASA Goddard Institute for Space Studies and Columbia Earth Institute, New York, NY, USA

${ }^{7}$ Department of Physics, Imperial College London, London, UK

${ }^{8}$ CICERO, Center for International Climate and Environmental Research-Oslo, Oslo, Norway

${ }^{9}$ Met Office Hadley Centre, Exeter, UK

${ }^{10}$ National Institute of Water and Atmospheric Research, Lauder, New Zealand

${ }^{11}$ Royal Netherlands Meteorological Institute, De Bilt, the Netherlands

${ }^{12}$ Lawrence Livermore National Laboratory, Livermore, California, USA

${ }^{13}$ Canadian Centre for Climate Modeling and Analysis, Environment Canada, Victoria, British Columbia, Canada

${ }^{14}$ NASA Goddard Space Flight Centre, Greenbelt, Maryland, USA

${ }^{15}$ Universities Space Research Association, Columbia, MD, USA

${ }^{16}$ NOAA Geophysical Fluid Dynamics Laboratory, Princeton, New Jersey, USA

${ }^{17}$ Laboratoire des Sciences du Climat et de l'Environment, Gif-sur-Yvette, France

${ }^{18}$ Department of Earth and Environmental Science, Graduate School of Environmental Studies, Nagoya University, Nagoya, Japan

${ }^{19}$ National Institute for Environmental Studies, Tsukuba-shi, Ibaraki, Japan

${ }^{20}$ GAME/CNRM, Météo-France, CNRS - Centre National de Recherches Météorologiques, Toulouse, France

${ }^{21}$ Agenzia Nazionale per le Nuove Tecnologie, l'energia e lo Sviluppo Economico Sostenibile (ENEA), Bologna, Italy

${ }^{22}$ Deutsches Zentrum für Luft- und Raumfahrt (DLR), Institut für Physik der Atmosphäre, Oberpfaffenhofen, Germany

${ }^{23}$ NASA Jet Propulsion Laboratory, Pasadena, California, USA

${ }^{24}$ Lancaster Environment Centre, University of Lancaster, Lancaster, UK

${ }^{25}$ Centre for Atmospheric Science, University of Cambridge, UK

* now at: Lancaster Environment Centre, University of Lancaster, Lancaster, UK

** now at: Department of Meteorology, University of Reading, UK

Correspondence to: D. S. Stevenson (david.s.stevenson@ed.ac.uk)

Received: 31 July 2012 - Published in Atmos. Chem. Phys. Discuss.: 4 October 2012

Revised: 16 February 2013 - Accepted: 21 February 2013 - Published: 15 March 2013 
Abstract. Ozone $\left(\mathrm{O}_{3}\right)$ from 17 atmospheric chemistry models taking part in the Atmospheric Chemistry and Climate Model Intercomparison Project (ACCMIP) has been used to calculate tropospheric ozone radiative forcings (RFs). All models applied a common set of anthropogenic emissions, which are better constrained for the present-day than the past. Future anthropogenic emissions follow the four Representative Concentration Pathway (RCP) scenarios, which define a relatively narrow range of possible air pollution emissions. We calculate a value for the pre-industrial (1750) to present-day (2010) tropospheric ozone RF of $410 \mathrm{~mW} \mathrm{~m}^{-2}$. The model range of pre-industrial to present-day changes in $\mathrm{O}_{3}$ produces a spread $( \pm 1$ standard deviation) in $\mathrm{RFs}$ of $\pm 17 \%$. Three different radiation schemes were used we find differences in RFs between schemes (for the same ozone fields) of $\pm 10 \%$. Applying two different tropopause definitions gives differences in RFs of $\pm 3 \%$. Given additional (unquantified) uncertainties associated with emissions, climate-chemistry interactions and land-use change, we estimate an overall uncertainty of $\pm 30 \%$ for the tropospheric ozone RF. Experiments carried out by a subset of six models attribute tropospheric ozone RF to increased emissions of methane $(44 \pm 12 \%)$, nitrogen oxides $(31 \pm 9 \%)$, carbon monoxide $(15 \pm 3 \%)$ and non-methane volatile organic compounds $(9 \pm 2 \%)$; earlier studies attributed more of the tropospheric ozone RF to methane and less to nitrogen oxides. Normalising RFs to changes in tropospheric column ozone, we find a global mean normalised $\mathrm{RF}$ of $42 \mathrm{~mW} \mathrm{~m}^{-2} \mathrm{DU}^{-1}$, a value similar to previous work. Using normalised RFs and future tropospheric column ozone projections we calculate future tropospheric ozone RFs ( $\mathrm{mW} \mathrm{m}^{-2}$; relative to 1750) for the four future scenarios (RCP2.6, RCP4.5, RCP6.0 and RCP8.5) of 350, 420, 370 and 460 (in 2030), and 200, 300, 280 and 600 (in 2100). Models show some coherent responses of ozone to climate change: decreases in the tropical lower troposphere, associated with increases in water vapour; and increases in the sub-tropical to mid-latitude upper troposphere, associated with increases in lightning and stratosphere-to-troposphere transport. Climate change has relatively small impacts on global mean tropospheric ozone RF.

\section{Introduction}

Ozone $\left(\mathrm{O}_{3}\right)$ is a radiatively active gas in Earth's atmosphere, interacting with down-welling and up-welling solar (shortwave, SW) and terrestrial (longwave, LW) radiation. Any changes in the atmospheric distribution of ozone contribute to the radiative forcing of climate change (e.g., Lacis et al., 1990; Forster et al., 2007). The focus of this paper is the troposphere, where ozone is thought to have substantially increased since the pre-industrial era, exerting a warming influence on surface climate.
Tropospheric ozone is a secondary pollutant produced during the photochemical oxidation of methane $\left(\mathrm{CH}_{4}\right)$, carbon monoxide $(\mathrm{CO})$ and non-methane volatile organic compounds (NMVOC) in the presence of nitrogen oxides $\left(\mathrm{NO}_{\mathrm{x}}\right)$ (Crutzen, 1974; Derwent et al., 1996). Downwards transport of ozone from the stratosphere is also an important source of tropospheric ozone (Stohl et al., 2003; Hsu and Prather, 2009). Completing its budget, ozone is removed from the troposphere by several chemical reactions (Crutzen, 1974), and is also dry deposited at the surface, mainly to vegetation (Fowler et al., 2009).

Emissions of ozone precursors from anthropogenic and biomass burning sources have changed (generally risen) dramatically since the pre-industrial era (Lamarque et al., 2010), tending to drive up tropospheric ozone concentrations. Increasingly sophisticated models of atmospheric chemistry, transport, and surface exchange, driven by emission estimates, and sometimes coupled to climate models, have been used to simulate the rise of ozone since industrialisation (Hough and Derwent, 1990; Crutzen and Zimmerman, 1991; Berntsen et al., 1997; Wang and Jacob, 1998; Gauss et al., 2006).

Modelled increases in ozone are, however, difficult to evaluate against observations. Past estimates of many atmospheric constituents can be derived from analyses of air trapped in bubbles during ice formation (Wolff, 2011), but ozone is too reactive to be preserved in this way. Direct measurements of tropospheric ozone concentrations prior to the 1970s are also extremely limited (Volz and Kley, 1988; Staehelin et al., 1994), and most early measurements used relatively crude techniques, such as Schönbein papers (Rubin, 2001), that are subject to contamination from compounds other than ozone (Pavelin et al., 1999). Only in the last few decades have observation networks and analytical methods developed sufficiently to allow a global picture of ozone's distribution in the troposphere to emerge (Fishman et al., 1990; Logan, 1999; Oltmans et al., 2006; Thouret et al., 2006). Observational data have been used to analyse past trends (e.g., Cooper et al., 2010; Logan et al., 2012; Parrish et al., 2012; Tilmes et al., 2012; Wilson et al., 2012; Oltmans et al., 2013). These studies indicate that: (i) inter-annual variability in ozone, and in some cases changes in observing techniques, make trends difficult to observe; nevertheless, (ii) there is good evidence that Northern Hemisphere midlatitude ozone increased by $\sim 1 \% \mathrm{yr}^{-1}$ from $\sim 1950-2000$ (i.e. roughly doubled); and (iii) this growth has slowed or stopped over the last decade or so, possibly related to emissions controls.

Although changes in anthropogenic precursor emissions have probably been the main driver of ozone change, several other factors may also have contributed. Natural sources of precursor emissions (e.g., wetland $\mathrm{CH}_{4}$, soil and lightning $\mathrm{NO}_{\mathrm{x}}$, biogenic NMVOCs) show significant variability and have probably also changed since the pre-industrial era, but these changes are highly uncertain (e.g., Arneth et 
al., 2010). The stratospheric source has probably been affected by stratospheric ozone depletion, and is forecast to change in the future, via ozone recovery and acceleration of the Brewer-Dobson circulation (Hegglin and Shepherd, 2009; Zeng et al., 2010; SPARC-CCMVal, 2010), although attempts to diagnose circulation changes from observations have given ambiguous results (Engel et al., 2009; Lin et al., 2009; Ray et al., 2010; Young et al., 2012). Ozone's removal, via chemical, physical and biological processes is also subject to variability and change. Increases in absolute humidity (driven by warming), changes in ozone's distribution, and changes in hydroxyl $(\mathrm{OH})$ and peroxy $\left(\mathrm{HO}_{2}\right)$ radicals, have all tended to increase chemical destruction of ozone (Johnson et al., 2001; Stevenson et al., 2006; Isaksen et al., 2009). Dry deposition of ozone at the surface, and to vegetation in particular, has been influenced by land-use change, but also by changes in climate and $\mathrm{CO}_{2}$ abundance (Sanderson et al., 2007; Sitch et al., 2007; Fowler et al., 2009; Andersson and Engardt, 2010; Ganzeveld et al., 2010; Wu et al., 2012). Fluctuations in these natural sources and sinks are driven by climate variability; climate change and land-use change may also have contributed towards long-term trends in ozone (Stevenson et al., 2005).

We use the concept of radiative forcing (RF) to quantify the impacts of tropospheric ozone changes on Earth's radiation budget since the pre-industrial period. Specifically, in this paper we follow the Intergovernmental Panel on Climate Change (IPCC) and use the following definition of RF from their Third Assessment Report (Ramaswamy et al., 2001): "The change in the net (down minus up) irradiance (solar plus longwave; in $\mathrm{W} \mathrm{m}^{-2}$ ) at the tropopause after allowing for stratospheric temperatures to readjust to radiative equilibrium, but with surface and tropospheric temperatures and state held fixed at unperturbed values."

Previous estimates of the tropospheric ozone RF (e.g., Gauss et al., 2006) span the range $250-650 \mathrm{~mW} \mathrm{~m}^{-2}$, with a central value of $350 \mathrm{~mW} \mathrm{~m}^{-2}$ for the RF from 1750-2005 (Forster et al., 2007). Skeie et al. (2011) recently estimated a value of $440 \mathrm{~mW} \mathrm{~m}^{-2}$, with an uncertainty of $\pm 30 \%$, using one of the models we also use in this study. Cionni et al. (2011) calculated ozone RFs for the IGAC/SPARC (International Global Atmospheric Chemistry/Stratospheric Processes and their Role in Climate) ozone database, and found a tropospheric ozone RF (1850s-2000s) of $230 \mathrm{~mW} \mathrm{~m}^{-2}$, using an earlier version of the main radiation scheme used here. Using an updated version of this radiation scheme with exactly the same ozone fields we find an equivalent, and presumed more accurate, value of $320 \mathrm{~mW} \mathrm{~m}^{-2}$. The tropospheric part of the IGAC/SPARC ozone database was constructed from early Atmospheric Chemistry and Climate Model Intercomparison Project (ACCMIP) integrations from two of the 17 models used here (GISS-E2-R and NCARCAM3.5). Through the use of additional models, we consider the multi-model mean results presented here to be a more ro- bust estimate of atmospheric composition change than the IGAC/SPARC database.

It is useful to understand how specific emissions of ozone's precursors have driven up its concentration (e.g., Wild et al., 2012). Model experiments carried out by Shindell et al. $(2005,2009)$ attributed pre-industrial to present-day ozone changes to increases in $\mathrm{CH}_{4}, \mathrm{NO}_{\mathrm{x}}, \mathrm{CO}$ and NMVOC emissions, finding that methane emissions were responsible for most of the ozone change. These emissions also influence the oxidising capacity of the atmosphere in general, and affect a range of radiatively active species beyond ozone, including methane and secondary aerosols (Shindell et al., 2009).

In this paper, we present results from global models participating in the ACCMIP (see www.giss.nasa.gov/projects/ accmip). Within ACCMIP, multiple models simulated atmospheric composition between 1850-2100. Lamarque et al. (2013) give an overview of ACCMIP and present detailed descriptions of the participating models and model simulations. Shindell et al. (2012) describe total radiative forcings, particularly those from aerosols; Lee et al. (2012) further focus on black carbon aerosol. Young et al. (2013) describe the ozone results in detail, including a range of comparisons with observations. Fiore et al. (2012) review air quality and climate change, and present future ozone projections from the ACCMIP models. Bowman et al. (2012) focus on comparisons of modelled ozone with measurements from TES (Tropospheric Emission Spectrometer). Voulgarakis et al. (2013) and Naik et al. (2012) document the evolution of the oxidising capacity of the atmosphere, especially $\mathrm{OH}$ and its impact on methane lifetime.

This paper looks in detail at tropospheric ozone RFs from the ACCMIP simulations. In Sect. 2, the models used and the experiments they performed are described. Results of simulated ozone and resulting radiative forcings are presented in Sect. 3; these are discussed and conclusions are drawn in Sect. 4. For conciseness, the main text focusses on generalised results (often presented as the multi-model mean) and specific results from individual models are predominantly presented in the Supplement.

\section{Methods}

\subsection{Models employed}

Results from 17 different models are analysed here (Table 1). Detailed model descriptions are provided in Lamarque et al. (2013); for model Q (TM5) see: Huijnen et al. (2010) and Von Hardenberg et al. (2012). All are global atmospheric chemistry models, and most are coupled to climate models, which provide the driving meteorological fields. Climate model output of sea-surface temperatures and sea-ice concentrations (SST/SIC) from prior CMIP5 runs typically provide the lower boundary conditions; well-mixed atmospheric 
Table 1. Models and experiment run lengths (in years). All models ran with emissions for the 1850s and 2000s; the years specified correspond to the years specified for the climate (SST/SIC).

\begin{tabular}{llllll}
\hline & \multicolumn{5}{c}{ Experiments (as used in this paper) } \\
\cline { 2 - 5 } Model & $1850 \mathrm{~s}^{\mathrm{a}}$ & $2000 \mathrm{~s}^{\mathrm{b}}$ & Attrib $^{\mathrm{c}}$ & $\Delta$ Clim $^{\mathrm{d}}$ & Future $^{\mathrm{e}}$ \\
\hline A. CESM-CAM-superfast & 10 & 10 & - & 10 & YnYY \\
B. CICERO-OsloCTM2 & $1(2006)$ & $1(2006)$ & 1 & - & YYnY \\
C. CMAM & 10 & 10 & - & - & $\mathrm{nYnY}$ \\
D. EMAC & 10 & 10 & - & - & $\mathrm{nYnY}$ \\
E. GEOSCCM & $10(1870 \mathrm{~s})$ & $14(1996-)$ & - & - & $\mathrm{nnnn}$ \\
F. GFDL-AM3 & $10(1860 \mathrm{~s})$ & 10 & - & 10 & YYYY \\
G. GISS-E2-R & $10(\times 5)$ & $10(\times 5)$ & - & 40 & YYYY \\
H. GISS-E2-R-TOMAS & 10 & 10 & - & 10 & nnnn \\
I. HadGEM2 & $10(1860 \mathrm{~s})$ & 10 & - & 10 & YYnY \\
J. HadGEM2-ExtTC & $10(2000 \mathrm{~s})$ & 10 & 10 & - & nnnn \\
K. LMDzORINCA & 10 & $5(1996-)$ & - & - & YYYY \\
L. MIROC-CHEM & $11(1850-)$ & $11(2000-)$ & - & $5(1850-)$ & YnYY \\
M. MOCAGE & $4(1850-)$ & $4(2000-)$ & - & $4(1850-)$ & YnYY \\
N. NCAR-CAM3.5 & $8(1852-)$ & $8(2002-)$ & 8 & $8(1852-)$ & YYYY \\
O. STOC-HadAM3 & 10 & 10 & 10 & 10 & YnnY \\
P. UM-CAM & 10 & $10(1996-)$ & 10 & 10 & YYnY \\
Q. TM5 & $1(2006)$ & $1(2006)$ & 1 & - & nnnn \\
\hline
\end{tabular}

${ }^{a}$ Where models did not run $1850-1859$ or $1851-1860$, the climate model decade ran is indicated. Where other than 10 yr were ran, the starting year is shown.

b Where models did not run 2000-2009 or 2001-2010, the climate model years ran are indicated. Where other than 10

yr were ran, the starting year is shown.

${ }^{c}$ Details of the attribution experiments are given in Sect. 3.1.2.

$\mathrm{d}$ Details of the climate experiments are given in Sect. 3.3.

e The code shown corresponds to the four future scenarios (RCP2.6, RCP4.5, RCP6.0 and RCP8.0, in order). "Y"

indicates that the scenario was run, " $n$ " indicates that it was not.

${ }^{f}$ Model G ran five ensembles of the 1850s and 2000s experiments, and an average of the five ensembles is used.

greenhouse gas concentrations are also specified. Three models (B, Q and $\mathrm{M})$ are chemistry-transport models, driven by offline meteorological analyses (B and Q) or offline output from a climate model (M). Additionally, models B and Q provide only a single year's output for each experiment and were run with the same meteorology in each case. In all other models, the chemistry module is embedded within a general circulation model. With the exception of models $\mathrm{O}$ and $\mathrm{P}$, the calculated chemical fields are used in the climate model's radiation scheme; i.e. they are fully coupled chemistry-climate models (CCM). Models $\mathrm{G}$ and $\mathrm{H}$ are two versions of GISSE2-R, but set up in different ways: $G$ has a fully interactive coupled ocean (the only model with this) whilst $\mathrm{H}$ uses SST/SIC from GISS-E2-R but also includes a more sophisticated aerosol microphysics scheme instead of the simpler mass-based scheme used in G. Models I and J are two versions of HadGEM2: I uses a relatively simple tropospheric chemistry scheme, whereas $\mathrm{J}$ has a more detailed scheme with several hydrocarbons. Several models (C, D, E, F, G, $\mathrm{H}, \mathrm{L}, \mathrm{M}$, and $\mathrm{N}$ ) include detailed stratospheric chemistry schemes; tropospheric schemes range from simple methane oxidation (C) through models with a basic representation of NMVOCs (A, G, H, I, and P) to those with more detailed hydrocarbon schemes (B, D, E, F, J, K, L, M, N, O and Q). In addition, some models include interactions between aerosols and gas-phase chemistry (B, F, G, H, I, J, K, L, N, and Q).

Models without detailed stratospheric chemistry handled their upper levels in a variety of different ways. Model A simulated stratospheric ozone using the LINOZ scheme (McLinden et al., 2000). Model B used monthly model climatological values of ozone and nitrogen species, except in the three lowermost layers of the stratosphere (approximately $2.5 \mathrm{~km}$ ) where the tropospheric chemistry scheme is applied to account for photochemical ozone production (Skeie et al., 2011). Models I, J, K, O, P and Q all used the IGAC/SPARC ozone database (Cionni et al., 2011) to prescribe ozone in the stratosphere. In models I and J, ozone is overwritten in all model levels which are 3 levels (approximately $3-4 \mathrm{~km}$ ) above the tropopause. Model $\mathrm{O}$ used the ozone fields together with vertical winds, to calculate a vertical ozone flux at $100 \mathrm{hPa}$, added as an ozone source at these levels in regions of descent. Model $\mathrm{P}$ prescribed ozone at pressures below $100 \mathrm{hPa}$ between $50^{\circ} \mathrm{S}-50^{\circ} \mathrm{N}$ and pressures below $150 \mathrm{hPa}$ poleward of $50^{\circ}$, and model $\mathrm{Q}$ at pressures below $45 \mathrm{hPa}$ between $30^{\circ} \mathrm{S}-30^{\circ} \mathrm{N}$ and pressures below $90 \mathrm{hPa}$ poleward of $30^{\circ}$.

Some models allowed natural emissions of ozone precursors to vary with climate; others fixed these sources (Table 2). 
Table 2. Natural emissions (lightning $\mathrm{NO}_{\mathrm{x}}$, biogenic isoprene, soil $\mathrm{NO}_{\mathrm{x}}$ ) in 1850 s and 2000s. Two models (C and I) that did not include isoprene in their chemical schemes included surrogate emissions of CO. Some values are not available (n/a); where values are not available, but models ran with constant present-day (PD) values, this is indicated.

\begin{tabular}{|c|c|c|c|c|c|c|}
\hline \multirow[t]{2}{*}{ Model } & \multicolumn{2}{|c|}{ Lightning $\mathrm{NO}_{\mathrm{x}} \mathrm{TgN} \mathrm{yr}^{-1}$} & \multicolumn{2}{|c|}{ Isoprene $\mathrm{Tg} \mathrm{yr}^{-1}$} & \multicolumn{2}{|c|}{ Soil $\mathrm{NO}_{\mathrm{x}} \mathrm{TgN} \mathrm{yr}^{-1}$} \\
\hline & $1850 \mathrm{~s}$ & $2000 \mathrm{~s}$ & $1850 \mathrm{~s}$ & $2000 \mathrm{~s}$ & $1850 \mathrm{~s}$ & $2000 \mathrm{~s}$ \\
\hline A. CESM-CAM-superfast & 3.8 & 4.2 & 500 & 500 & Constant PD & Constant PD \\
\hline B. CICERO-OsloCTM2 & 5.0 & 5.0 & 449 & 449 & 8.0 & 8.0 \\
\hline C. CMAM & 4.5 & 3.8 & $250 \mathrm{Tg} \mathrm{yr}^{-1} \mathrm{CO}$ & $250 \mathrm{Tg} \mathrm{yr}^{-1} \mathrm{CO}$ & 8.7 & 9.3 \\
\hline D. EMAC & 5.3 & 5.7 & 336 & 355 & 3.5 & 3.6 \\
\hline E. GEOSCCM & 5.0 & 5.0 & 411 & 470 & 6.9 & 7.2 \\
\hline F. GFDL-AM3 & 4.5 & 4.4 & 565 & 565 & 3.6 & 3.6 \\
\hline G. GISS-E2-R & 7.5 & 7.7 & 549 & 602 & 2.7 & 2.7 \\
\hline H. GISS-E2-R-TOMAS & 7.5 & 7.7 & 549 & 602 & 2.7 & 2.7 \\
\hline I. HadGEM2 & 1.2 & 1.2 & $475 \mathrm{Tg} \mathrm{yr}^{-1} \mathrm{CO}$ & $475 \mathrm{Tg} \mathrm{yr}^{-1} \mathrm{CO}$ & 5.6 & 5.6 \\
\hline J. HadGEM2-ExtTC & 6.4 & 6.4 & 656 & 521 & 5.6 & 5.6 \\
\hline K. LMDzORINCA & $\mathrm{n} / \mathrm{a}$ & $\mathrm{n} / \mathrm{a}$ & Constant PD & Constant PD & Constant PD & Constant PD \\
\hline L. MIROC-CHEM & 9.3 & 9.7 & Constant PD & Constant PD & Constant PD & Constant PD \\
\hline M. MOCAGE & 5.0 & 5.2 & 568 & 568 & 4.5 & 4.5 \\
\hline N. NCAR-CAM3.5 & 3.7 & 4.1 & 483 & 483 & $\mathrm{n} / \mathrm{a}$ & $\mathrm{n} / \mathrm{a}$ \\
\hline O. STOC-HadAM3 & 6.9 & 7.2 & 536 & 576 & 5.6 & 5.6 \\
\hline P. UM-CAM & 4.9 & 5.1 & 390 & 390 & 7.0 & 7.0 \\
\hline Q. TM5 & 5.5 & 5.5 & 524 & 524 & 5.0 & 5.0 \\
\hline
\end{tabular}

The models produce a range of results (see below), and each model has its own particular strengths and weaknesses. We know of no major model bugs or gross errors in the simulations presented here which might suggest that any of the models should be excluded. We have conducted a partial model evaluation (e.g., Young et al., 2013; Naik et al., 2012), and we can identify some models as outliers, although it is not clear that these outliers are necessarily the models that are most poorly representing the real world. Consequently, in our analysis we retain all models, and produce multi-model means and standard deviations based on all models. Outliers are discussed at various points in the following analysis.

\subsection{Model simulations}

The main experiments analysed here are multi-annual simulations for the 1850s and the 2000s. Every model performed these experiments. Table 1 shows the model run length for each experiment: typically $10 \mathrm{yr}$, but in a few cases longer or shorter. Model G ran five 10-yr ensemble members. In most cases, models simulated climates of the 1850s and 2000s, typically by specifying SST/SIC fields (typically decadally averaged from prior coupled ocean-atmosphere climate simulations) and setting well-mixed greenhouse gas concentrations at appropriate levels. Models B, J and Q ran with the same climate in the 1850 s as in their 2000 s runs, so only assess how emissions have changed composition; single year experiments are thus not unreasonable in these cases.

All models used anthropogenic emissions (including biomass burning emissions, which are partly anthropogenic and partly natural) from Lamarque et al. (2010). A consequence of this approach is that we cannot directly use our results to estimate uncertainties in ozone RF stemming from uncertainties in anthropogenic emissions. On the other hand, this harmonisation of all models to the same source of emissions removes a potentially large source of inter-model difference (cf. Gauss et al., 2006). However, as each model did not run exactly the same years to represent the 1850s and 2000s (see Table 1), and models used a range of values for natural emissions (Table 2) there are still some differences between models in the magnitude of the applied change in emissions (see Young et al., 2013, Fig. 1). Note that the model years specified in Table 1 refer to nominal years for the driving climate, but not for the emissions. These differences are added to by different chemistry schemes and decisions within each model of how to partition NMVOC emissions between individual species and/or to emit directly as $\mathrm{CO}$ emissions.

Most models ran with prescribed methane concentrations of around $791 \mathrm{ppbv}$ (1850s) and $1751 \mathrm{ppbv}$ (2000s) (Prinn et al., 2000; Meinshausen et al., 2011). One model (K) ran with methane emissions for the historical period, allowing methane concentrations to evolve, although they quite closely follow observations (Szopa et al., 2012).

Six of the models (Table 1) ran a series of attribution experiments, based on the 2000s simulations. In these, specific drivers of ozone change (anthropogenic emissions of $\mathrm{NO}_{\mathrm{x}}$, $\mathrm{CO}$, NMVOCs, and $\mathrm{CH}_{4}$ concentrations) were individually reduced to 1850 s levels. These experiments are closely related to previous studies with the GISS model (Shindell et 

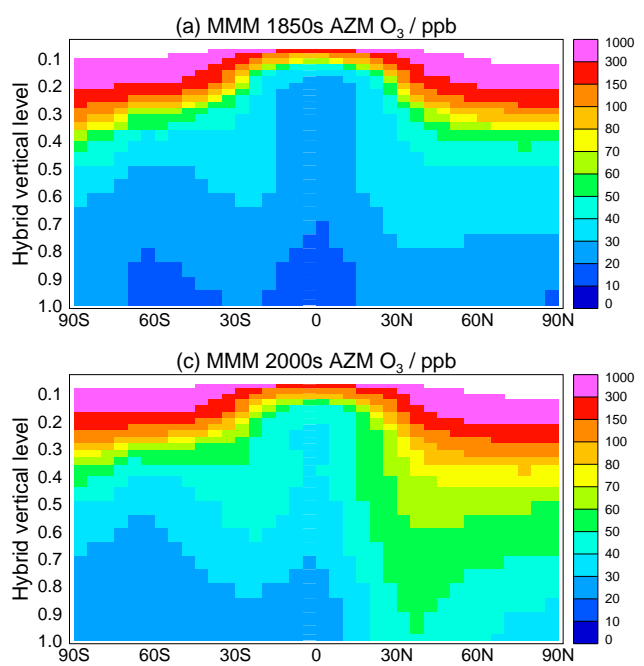

(e) MMM 2000s-1850s AZM $\Delta \mathrm{O}_{3} / \mathrm{ppb}$

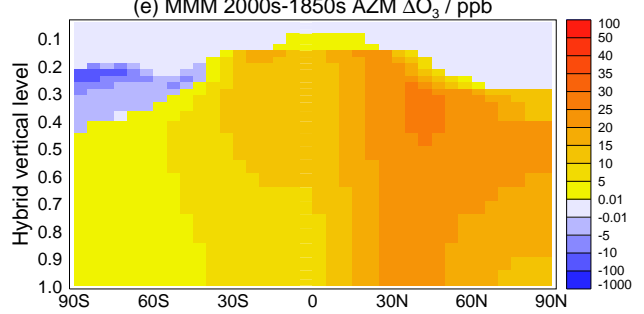

(b) MMM 1850s $\mathrm{ATC} \mathrm{O}_{3}(19.8) \mathrm{DU}$

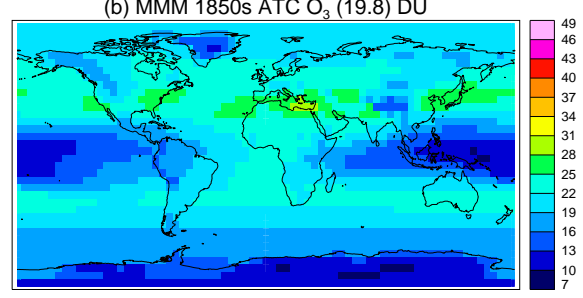

(d) MMM 2000s ATC O 3 (28.1) DU

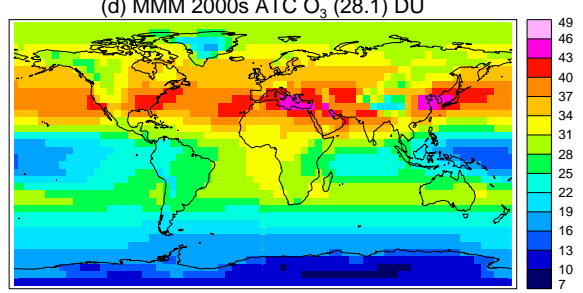

(f) MMM 2000s-1850s ATC $\Delta \mathrm{O}_{3}$ (8.4) DU

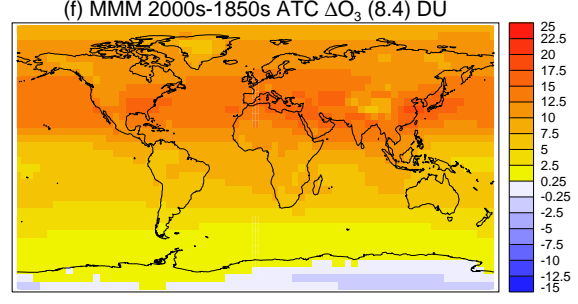

Fig. 1. Multi-model mean (MMM) annual zonal mean (AZM) ozone (ppb) and annual mean tropospheric column (ATC) ozone (DU), for the: 1850s (a-b), 2000s (c-d) and for the change 2000s-1850s (e-f). The MASKZMT tropopause is used, and area-weighted global mean values of ATC are given in brackets. Figure S1 (Supplement) shows equivalent plots for all individual models.

al., 2005, 2009), and allow us to attribute methane and ozone radiative forcings since the 1850 s to these individual drivers, although we do not consider how the individual drivers interact.

A subset of ten models (Table 1) ran experiments where they fixed emissions at 2000s levels, but applied an 1850s climate. These simulations allow us to investigate how climate change has contributed to the ozone change since the 1850s. Nine of these models also ran equivalent experiments for future climates.

Finally, most models (Table 1) ran additional historical and future simulations, using harmonized emissions from the Representative Concentration Pathway (RCP) scenarios, and prescribing methane concentrations (Meinshausen et al., 2011). Models $K$ and $G$ ran with methane emissions in the future, allowing methane concentrations to freely evolve. Ozone fields from these experiments are presented in detail by Young et al. (2013) - here we use future tropospheric column ozone changes in conjunction with normalised radiative forcings $\left(\mathrm{mW} \mathrm{m}^{-2} \mathrm{DU}^{-1}\right)$ to estimate future tropospheric ozone radiative forcings.

\subsection{Radiative forcing calculations}

Ozone fields were inserted into an offline version of the Edwards and Slingo (1996) radiation scheme, updated and described by Walters et al. (2011) (their Sect. 3.2). The scheme includes gaseous absorption in six bands in the SW and nine bands in the LW. The treatment of ozone absorption is as described by Zhong et al. (2008). The RF calculations use an updated version of the radiation code compared with those presented by Cionni et al. (2011), and it is found that these updates make substantial differences in the values. The updated calculations presented here supersede the RF calculations from Cionni et al. (2011) that were calculated with the older version of the radiation scheme and from two rather than 17 models in this study.

The offline code was set up so that all input fields except ozone remained fixed (at present-day values) - thus differences between two runs of the radiation code with different ozone yield the changes in fluxes of radiation due to ozone change alone. Monthly mean ozone fields were interpolated from each model to a common resolution: $5^{\circ}$ longitude by $5^{\circ}$ latitude, and 64 hybrid vertical levels up to $0.01 \mathrm{hPa}$. The vertical levels were chosen to be compatible with the base climatological fields (temperature, humidity, cloud fields), taken from a present-day simulation of the HadAM3 model 
Table 3. Changes in tropospheric column ozone (DU) and radiative forcing $\left(\mathrm{mW} \mathrm{m}^{-2}\right)$ for two different tropopause definitions (MASKZMT and MASK150). The mean and standard deviation (SD) excludes Model J.

\begin{tabular}{lrr|rr}
\hline Model & \multicolumn{2}{c|}{$\begin{array}{c}\text { Tropospheric column } \mathrm{O}_{3} \\
\text { change }(2000 \mathrm{~s}-1850 \mathrm{~s})\end{array}$} & \multicolumn{2}{c}{$\begin{array}{c}\text { Tropospheric } \mathrm{O}_{3} \\
\text { radiative forcing }\left(\mathrm{mW} \mathrm{m}^{-2}\right)\end{array}$} \\
\cline { 2 - 5 } & MASKZMT & MASK150 & MASKZMT & MASK150 \\
\hline A. CESM-CAM-superfast & 9.4 & 10.0 & 428 & 446 \\
B. CICERO-OsloCTM2 & 8.7 & 9.3 & 383 & 401 \\
C. CMAM & 7.2 & 7.6 & 315 & 322 \\
D. EMAC & 9.8 & 10.8 & 429 & 460 \\
E. GEOSCCM & 8.0 & 8.7 & 364 & 387 \\
F. GFDL-AM3 & 9.7 & 10.3 & 406 & 423 \\
G. GISS-E2-R & 7.9 & 8.3 & 286 & 314 \\
H. GISS-E2-R-TOMAS & 8.4 & 8.7 & 305 & 333 \\
I. HadGEM2 & 7.2 & 7.3 & 301 & 303 \\
J. HadGEM2-ExtTC & 8.2 & 8.4 & 315 & $\mathrm{n} / \mathrm{a}$ \\
K. LMDzORINCA & 7.9 & 8.2 & 344 & 351 \\
L. MIROC-CHEM & 8.4 & 9.2 & 376 & 402 \\
M. MOCAGE & 4.7 & 4.8 & 210 & 219 \\
N. NCAR-CAM3.5 & 9.3 & 10.2 & 406 & 433 \\
O. STOC-HadAM3 & 9.4 & 10.5 & 396 & 437 \\
P. UM-CAM & 8.5 & 8.7 & 371 & 376 \\
Q. TM5 & 9.3 & 10.0 & 399 & 422 \\
Mean \pm SD & $8.4 \pm 1.3$ & $8.9 \pm 1.5$ & $357 \pm 60$ & $377 \pm 65$ \\
\hline
\end{tabular}

(Pope et al., 2000; Tian and Chipperfield, 2005). Values for cloud particle effective radii were taken from the GRAPE (Global Retrieval of ATSR (Along Track Scanning Radiometer) cloud Parameters and Evaluation) dataset (Sayer et al., 2011).

To calculate an ozone radiative forcing, the code is applied as follows. A base calculation of radiation fluxes is performed, using multi-annually averaged monthly ozone data from the 1850s, for each column of the model atmosphere. The radiation calculation is then repeated, keeping everything the same, but using a different ozone field (e.g., from the 2000s). The change in net radiation at the tropopause between these two calculations gives the instantaneous radiative forcing. In this study, we only consider changes in tropospheric ozone, by overwriting ozone fields above the tropopause with climatological values taken from Cionni et al. (2011) (up to $1 \mathrm{hPa}$ ) and values from Li and Shine (1995) at higher altitudes.

By changing the ozone field, heating rates in the stratosphere will have changed. If such a change were to happen in the real atmosphere, stratospheric temperatures would respond quickly (days to months, e.g., Hansen et al., 1997) - much more quickly than the surface-troposphere system, which will adjust on multiannual timescales. A better estimate of the long-term forcing on the surface climate takes into account this short-term response of stratospheric temperatures (Forster et al., 2007). Stratospheric temperature adjustment was achieved by first calculating stratospheric heating rates for the base atmosphere. The stratosphere was as- sumed to be in thermal equilibrium, i.e. with dynamical heating exactly balancing the radiative heating. Furthermore, the dynamics were assumed to remain constant following a perturbation to ozone. Hence to maintain equilibrium, radiative heating rates must also remain unchanged. To achieve this, stratospheric temperatures were iteratively adjusted in the perturbed case, until stratospheric radiative heating rates returned to their base values. This procedure is called the fixed dynamical heating approximation (Ramanathan and Dickinson, 1979). Here we report annual mean forcings at the tropopause, after stratospheric temperature adjustment.

To explore some of the uncertainties associated with using different radiation codes and different baseline climatologies in the radiation calculations, we compare calculations with the Edwards-Slingo radiation scheme to results from similar schemes from the University of Oslo and the National Center for Atmospheric Research (NCAR). The Oslo radiative transfer calculations are performed with a broad band longwave scheme (Myhre and Stordal, 1997) and a model using the discrete ordinate method (Stamnes et al., 1988) for the shortwave calculations (see further description in Myhre et al., 2011). Meteorological data from ECMWF (European Centre for Medium-range Weather Forecasting) are used and stratospheric temperature adjustment is included. The NCAR calculations used the NCAR Community Climate System Model 4 offline radiative transfer model, also allowing stratospheric temperatures to adjust. Net LW and SW all-sky fluxes at the tropopause (based on a climatology of tropopause pressure from the NCAR/NCEP reanalyses) were computed 


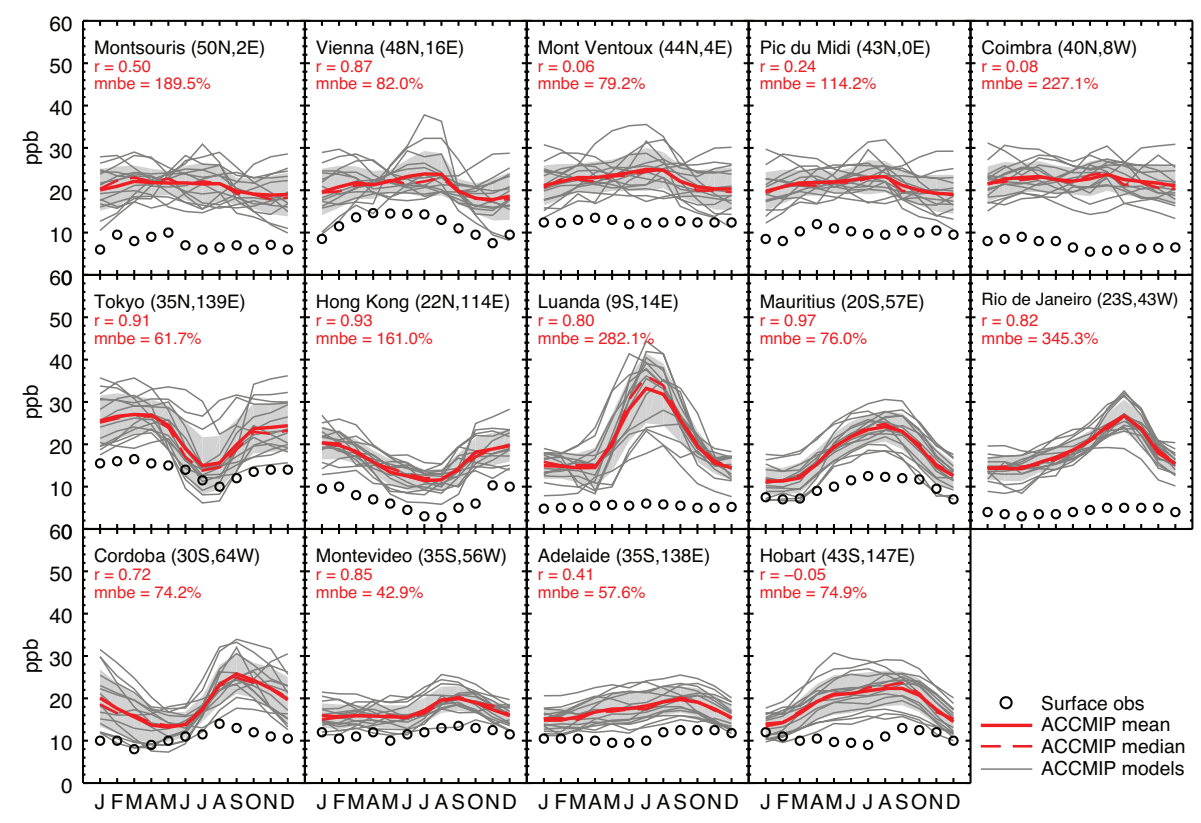

Fig. 2. Comparison of 1850 s modelled seasonal cycles of ozone (lines) with observations of ozone (circles) at 14 surface sites. The observations have large, but unquantified uncertainties, so no error bars are included. The correlation $(r)$ and the mean normalised bias error (mnbe) of the mean model to the observations are also shown for each site.

using the same conditions for all parameters except for the ozone distribution.

\section{Results}

\subsection{Pre-industrial (1850s) and present-day (2000s) simulations}

\subsubsection{Core ACCMIP experiments}

\section{Ozone distributions and their evaluation}

Figure 1 shows the multi-model mean (MMM) annual zonal mean (AZM) ozone (ppb) and annual tropospheric column (ATC) ozone (DU) for the 1850s and 2000s. All models are included in the MMM, with equal weighting. In the Supplement, Fig. S1 shows these quantities for all 17 models. In these figures, we use the same monthly zonal mean climatological tropopause (hereafter referred to as MASKZMT) for all models, based on the 2 PVU definition applied to presentday NCEP/NCAR reanalysis data (Cionni et al., 2011). We also calculate ozone changes and radiative forcing results using a different tropopause definition $\left(1850 \mathrm{~s} \mathrm{O}_{3}=150 \mathrm{ppb}\right.$; hereafter referred to as MASK150; as used in Young et al., 2013) to test how sensitive results are to this choice. The MASKZMT tropopause is the same for all models (and all time slices); the MASK150 tropopause is different for each model, but the same for all time slices of a given model. Table 3 compares global mean tropospheric column ozone changes using both definitions for all models. The two tropopause definitions produce only marginally different ozone column changes: with MASK150, the mean ozone column change is $6 \%$ larger (Table 3 ).

Detailed evaluation of simulated present-day ozone fields against a variety of observational data sets can be found elsewhere (Young et al., 2013). Overall, present-day distributions are similar to those presented by Stevenson et al. (2006) from the ACCENT PhotoComp model intercomparison. Evaluation of the 1850s ozone is considerably more difficult, given the lack of reliable measurements. Figure 2 shows simulated 1850s monthly mean annual cycles of ozone from the ACCMIP models, together with observations, at 14 surface sites where pre-industrial observations exist. As discussed in several previous papers, the pre-industrial observations are highly uncertain, as the methods used are readily contaminated by other common compounds, including sulphur dioxide and water vapour (e.g., Kedzie, 1877; Linvill et al., 1980; Anfossi et al., 1991; Rubin, 2001; Pavelin et al., 1999; Hauglustaine and Brasseur, 2001; Lamarque et al., 2005). The ACCMIP models generally overestimate these observations by about $10-15 \mathrm{ppb}$. Clearly, if 1850 s ozone levels were as low as the observations suggest, the higher modelled values will lead to an underestimate of the ozone increase up to present-day (Mickley et al., 2001). However, given that the models represent present-day ozone well, it is reasonable to assume that the values predicted by the models, when driven by pre-industrial emissions, are more representative of the pre-industrial atmosphere than the poorly constrained observations. Nevertheless, the lack of a rigorous method to 
(a) MMM 2000s-1850s $\mathrm{O}_{3} \mathrm{~T}$ SW RF ( 71) $\mathrm{mWm}^{-2}$

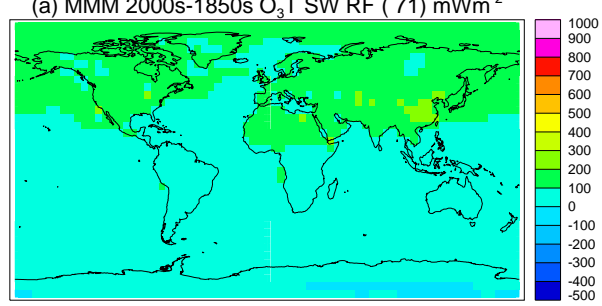

(c) MMM 2000s-1850s $\mathrm{O}_{3} \mathrm{~T}$ RF (355) $\mathrm{mWm}^{-2}$

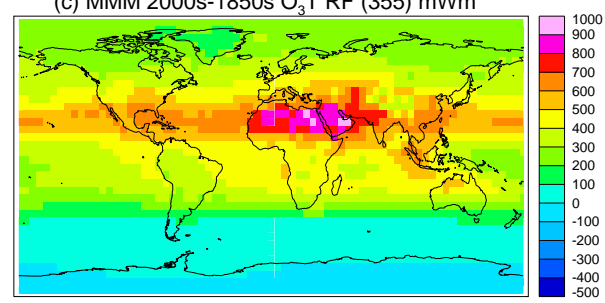

(b) MMM 2000s-1850s O T LW RF (283) $\mathrm{mWm}^{-2}$

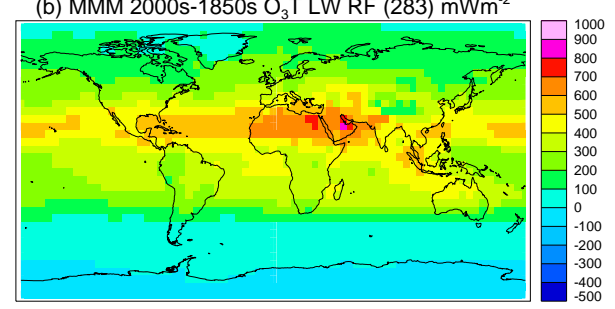

(d) MMM 2000s-1850s norm $\mathrm{O}_{3} \mathrm{~T}$ RF (42) $\mathrm{mWm}^{-2} \mathrm{DU}^{-1}$

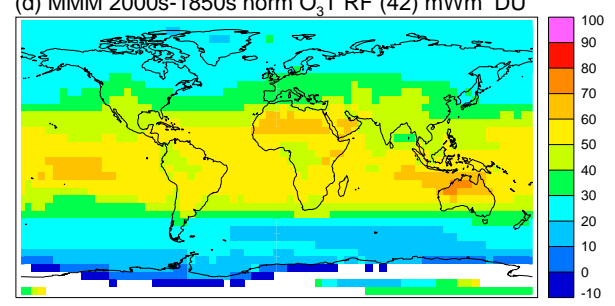

Fig. 3. Multi-model mean, annual mean tropospheric ozone radiative forcings ( $\mathrm{mW} \mathrm{m}^{-2}$ ), for: (a) $\mathrm{SW}$; (b) $\mathrm{LW}$; (c) total (SW+LW); and (d) total RF normalised by tropospheric column ozone change (Fig. 1f) ( $\left.\mathrm{mW} \mathrm{m}^{-2} \mathrm{DU}^{-1}\right)$. The normalised RF is masked (white boxes) where the change in ozone column is less than $0.25 \mathrm{DU}$. Area-weighted global mean values are given in brackets. Figure S2 shows equivalent plots for all individual models.

evaluate simulated pre-industrial ozone adds significant, but poorly quantified, uncertainty to our ozone RF estimates.

\section{Ozone changes}

Figure 1 also shows the MMM change (2000s-1850s) in AZM and ATC ozone for MASKZMT. Figure S1 shows the equivalent fields for all 17 models. Ozone generally increases throughout the troposphere, most strongly in the Northern Hemisphere sub-tropical upper troposphere. This mainly reflects the industrialised latitudes where emissions are concentrated, and the fact that the ozone lifetime is longer in the upper troposphere. Decreases in ozone are seen in the high latitudes of the Southern Hemisphere (SH) in many models (Figs. 1 and S1). This reflects the present-day ozone depletion (relative to the 1850s) of air transported downwards from the stratosphere, and is especially pronounced in models $M, G$ and $H$. This effect is strong enough in several models to produce decreases in tropospheric column ozone in high SH latitudes - which mainly reflects relatively high 1850s SH ozone values in these models (Fig. S1).

\section{Ozone radiative forcings}

Figure 3 shows maps of the multi-model annual mean radiative forcing $\left(\mathrm{mW} \mathrm{m}^{-2}\right)$ in the SW, $\mathrm{LW}$, and total $(\mathrm{SW}+\mathrm{LW})$, using MASKZMT. Table 3 and Fig. S2 show the total RFs for all 17 models; Fig. S3 shows the equivalent plot to Fig. 3 for ozone from the IGAC/SPARC database (Cionni et al., 2011). The LW RF peaks in regions where large ozone changes coincide with hot surface temperatures and cold tropopause temperatures (e.g., over the Sahara and Middle East). The
SW RF peaks where large ozone changes coincide with high underlying albedos (either reflective surfaces, such as deserts or ice, or low cloud). RFs are reduced over high altitude regions (e.g., Tibet, The Rocky Mountains, and Greenland) as there is less air mass, and hence less column ozone (see Fig. 1). Figure 3d shows the normalised total RF ( $\mathrm{mW}$ $\mathrm{m}^{-2} \mathrm{DU}^{-1}$ ) for MASKZMT; Fig. S2 shows this for all 17 models. Normalised RFs are highest in the tropics, where the temperature difference between the surface and tropopause is largest, and peak in relatively cloud-free regions over NW Australia. Similar distributions for normalised RFs have been found previously (e.g., Gauss et al., 2003, their Fig. 7).

In order to estimate the uncertainty associated with these RFs, we tested how the following processes and choices influenced results: (i) choice of tropopause definition; (ii) choice of radiation scheme; (iii) stratospheric adjustment; and (iv) inclusion/exclusion of clouds.

The tropopauses may be defined in several ways (e.g., Prather et al., 2011). The Edwards-Slingo (hereafter ES) scheme was run for all models using the two different tropopause definitions (MASKZMT and MASK150). MASK150 was also used to define the troposphere in some of the other ACCMIP papers (e.g., Young et al., 2013), and has been widely used in earlier studies (e.g., Prather et al., 2001; Stevenson et al., 2006). Radiation calculations with the different tropopause differ due to changes in: (i) tropospheric column ozone; (ii) the altitude of where the net flux changes are output; and (iii) the altitude above which stratospheric temperatures are adjusted. The initial temperature profile remains unchanged. Global mean 1850s-2000s column ozone changes are larger by $0.1-1.1 \mathrm{DU}(1-12 \%)$, 
Table 4. Influence of stratospheric adjustment and clouds (\% change in ozone RFs when included) in the Edwards-Slingo (E-S) and Oslo schemes. First two rows are for all models: values are means and standard deviations. Lower rows are just for model B.

\begin{tabular}{|c|c|c|c|c|c|c|c|c|}
\hline \multirow[t]{2}{*}{ Radiation scheme } & \multirow[t]{2}{*}{ Models } & \multirow[t]{2}{*}{ Tropopause mask } & \multicolumn{3}{|c|}{$\begin{array}{c}\text { Influence of stratospheric } \\
\text { adjustment }(\%)\end{array}$} & \multicolumn{3}{|c|}{ Influence of clouds (\%) } \\
\hline & & & SW & LW & net & SW & LW & net \\
\hline E-S & all & MASKZMT & 0 & $-24 \pm 1$ & $-20 \pm 1$ & $20 \pm 4$ & $-16 \pm 1$ & $-12 \pm 1$ \\
\hline E-S & all & MASK150 & 0 & $-26 \pm 1$ & $-22 \pm 1$ & $21 \pm 5$ & $-16 \pm 1$ & $-2 \pm 1$ \\
\hline E-S & $\mathrm{B}$ & MASKZMT & 0 & -25 & -21 & 21 & -17 & -12 \\
\hline E-S & $\mathrm{B}$ & MASK150 & 0 & -27 & -22 & 22 & -16 & -12 \\
\hline Oslo & $\mathrm{B}$ & MASK150 & - & - & - & 35 & -30 & -22 \\
\hline Oslo & $\mathrm{B}$ & MASKOslo* & 0 & -21 & -17 & - & - & - \\
\hline
\end{tabular}

* Results using the Oslo model tropopause.

Table 5. Comparison of ozone RFs from different radiation schemes for both the clear-sky, instantaneous case, and cloudy-sky, stratospherically adjusted case. Results are shown for model B alone (to allow direct comparison of E-S and Oslo schemes), 11 models (ACEFGIKLMNP; to allow direct comparison of E-S and NCAR schemes), and all models (for context).

\begin{tabular}{lllll|lll}
\hline & & \multicolumn{3}{c|}{$\begin{array}{c}\text { Clear-sky, instantaneous } \\
\mathrm{O}_{3} \mathrm{RF}\left(\mathrm{mW} \mathrm{m}^{-2}\right)\end{array}$} & \multicolumn{3}{c}{$\begin{array}{c}\text { Cloudy-sky, stratospherically } \\
\text { adjusted } \mathrm{O}_{3} \mathrm{RF}\left(\mathrm{mW} \mathrm{m}^{-2}\right)\end{array}$} \\
\cline { 3 - 9 } & Tropopause mask & SW & LW & net & SW & LW & net \\
\hline E-S (B) & MASKZMT & 62 & 491 & 552 & 75 & 309 & 384 \\
E-S (B) & MASK150 & 64 & 521 & 585 & 78 & 322 & 401 \\
Oslo (B) & MASK150 & 72 & 488 & 560 & 97 & 264 & 361 \\
Oslo (B) & MASKOslo* & 70 & 470 & 540 & 94 & 259 & 353 \\
E-S (11) & MASKZMT & $58 \pm 9$ & $437 \pm 87$ & $495 \pm 96$ & $70 \pm 13$ & $277 \pm 51$ & $347 \pm 64$ \\
E-S (11) & MASK150 & $58 \pm 9$ & $463 \pm 93$ & $521 \pm 101$ & $71 \pm 12$ & $291 \pm 56$ & $361 \pm 68$ \\
NCAR(11) & MASK150 & - & - & - & $83 \pm 16$ & $243 \pm 8$ & $326 \pm 100$ \\
E-S (all) & MASKZMT & $60 \pm 9$ & $452 \pm 82$ & $512 \pm 90$ & $72 \pm 12$ & $286 \pm 49$ & $358 \pm 60$ \\
E-S (all) & MASK150 & $61 \pm 8$ & $483 \pm 89$ & $543 \pm 96$ & $74 \pm 12$ & $303 \pm 54$ & $377 \pm 65$ \\
\hline
\end{tabular}

* Results using the Oslo model tropopause.

and net ozone RFs larger by $5-41 \mathrm{~mW} \mathrm{~m}^{-2}(1-10 \%)$, with MASK150 compared to MASKZMT (Table 3; the ranges quoted cover the full model spread).

We additionally calculated instantaneous (i.e. without stratospheric temperature adjustment) tropospheric ozone RFs with the E-S scheme, both leaving clouds as before, and also for clear skies (i.e. removing all clouds). We only use a single representation of cloud distributions (from the 64-level HadAM3 model) in the E-S calculations; cloud fields from individual models were not used. We found very similar results for the influence of stratospheric adjustment and clouds in the E-S scheme for all models; results are summarised in Table 4. Model B sits close to the mean values. The Oslo radiation scheme was used to repeat these calculations for just model B (Table 4). Stratospheric adjustment has a slightly smaller effect in the Oslo scheme compared to E-S, whereas clouds have a stronger influence. The Oslo radiation scheme uses its own cloud fields; we have not compared these to the cloud fields used in the E-S calculations.

Comparing the clear-sky instantaneous results between the E-S and Oslo schemes for MASK150 (Table 5) indicates that the Oslo LW RFs are $6 \%$ lower than E-S, but that the SW RFs are $13 \%$ higher. Since these differences are in opposite directions, the difference between schemes for the net RF is smaller (Oslo is $4 \%$ less than E-S).

Comparing stratospherically adjusted RFs between these two schemes (Table 5) (for MASK150) shows that the SW $\mathrm{RF}$ is $24 \%$ higher in the Oslo scheme, but the LW RF is $18 \%$ lower, and the net RF is $10 \%$ lower. A similar result is found when comparing the E-S and NCAR schemes (Table 5): the NCAR scheme has $17 \%$ higher values for SW RF, $16 \%$ lower LW RF values, and net RFs that are $10 \%$ lower. These comparisons between radiation schemes are used to infer levels of uncertainty associated with radiation calculations (see Sect. 4).

\subsubsection{Attribution experiments}

A subset of six models ran a series of attribution experiments, based on the 2000s simulations (Tables 1 and 6). Specific drivers of ozone change (anthropogenic emissions of $\mathrm{NO}_{\mathrm{x}}$, $\mathrm{CO}$, NMVOCs, and $\mathrm{CH}_{4}$ concentrations) were individually 
Table 6. Attribution experiments.

\begin{tabular}{llllll}
\hline Attribution experiment & Climate & {$\left[\mathrm{CH}_{4}\right]$} & \multicolumn{2}{c}{ Anthropogenic Emissions } \\
\cline { 4 - 6 } & & & $\mathrm{NO}_{\mathrm{x}}$ & $\mathrm{CO}$ & NMVOC \\
\hline \#0 Em1850CH 418501 & $2000 \mathrm{~s}$ & $1850 \mathrm{~s}$ & $1850 \mathrm{~s}$ & $1850 \mathrm{~s}$ & $1850 \mathrm{~s}$ \\
\#1 Em2000CH $42000^{2}$ & $2000 \mathrm{~s}$ & $2000 \mathrm{~s}$ & $2000 \mathrm{~s}$ & $2000 \mathrm{~s}$ & $2000 \mathrm{~s}$ \\
\#2 Em2000CH 41850 & $2000 \mathrm{~s}$ & $1850 \mathrm{~s}$ & $2000 \mathrm{~s}$ & $2000 \mathrm{~s}$ & $2000 \mathrm{~s}$ \\
\#3 Em2000NO 1850 & $2000 \mathrm{~s}$ & $2000 \mathrm{~s}$ & $1850 \mathrm{~s}$ & $2000 \mathrm{~s}$ & $2000 \mathrm{~s}$ \\
\#4 Em2000CO1850 & $2000 \mathrm{~s}$ & $2000 \mathrm{~s}$ & $2000 \mathrm{~s}$ & $1850 \mathrm{~s}$ & $2000 \mathrm{~s}$ \\
\#5 Em2000NMVOC1850 & $2000 \mathrm{~s}$ & $2000 \mathrm{~s}$ & $2000 \mathrm{~s}$ & $2000 \mathrm{~s}$ & $1850 \mathrm{~s}$ \\
\hline
\end{tabular}

${ }^{1}$ Experiment Em $1850 \mathrm{CH}_{4} 1850$ is the same as the core 1850 s experiment for models B, J, Q.

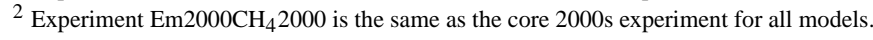

reduced to 1850 s levels. In all these experiments, the driving meteorology was identical to the base 2000s case; thus differences between simulations isolate the influence of the specific component that is changed.

All of the 1850s-2000s attribution experiments were carried out with fixed methane concentrations. These experiments spin-up quickly (i.e. within about a year), and are thus relatively easily performed. Experiments with freelyevolving methane concentrations driven by methane emissions would take several methane lifetimes to adjust (i.e. decades), and are thus less practical for a multi-model intercomparison project like the one conducted here. For the methane experiment, concentrations were reduced to 1850s levels (791 ppb), and kept fixed at this level. In the other experiments, methane was fixed at present-day levels (1751 ppb), and emissions of $\mathrm{NO}_{\mathrm{x}} / \mathrm{CO} / \mathrm{NMVOC}$ were reduced to their 1850s levels. Fixing methane concentrations has important consequences for how these experiments are interpreted, and this set-up differs from previous approaches, where methane emissions were changed, and methane concentrations were allowed to respond (Shindell et al., 2005, 2009).

Differences in ozone fields between attribution experiments and the year 2000s base case suggests that the largest component of the 1850s-2000s ozone change comes from $\mathrm{NO}_{\mathrm{x}}$ emissions, the next largest from changes in methane, and relatively small contributions from changes in $\mathrm{CO}$ and NMVOC emissions (e.g., Figs. S4 and S5 show ozone changes and radiative forcings for model $\mathrm{B}$ ). However, in the $\mathrm{NO}_{\mathrm{x}}, \mathrm{CO}$ and $\mathrm{NMVOC}$ attribution experiments, we wish to diagnose how methane (and ozone) concentrations would have changed if methane emissions were fixed, and methane concentrations were free to adjust. Similarly, for the methane experiment, we need to diagnose how methane and ozone concentrations would adjust to a change in methane emissions.

For example, in the attribution experiment where anthropogenic $\mathrm{NO}_{\mathrm{x}}$ emissions are reduced to 1850 s levels, the methane concentration is held fixed at $1751 \mathrm{ppb}$. Because $\mathrm{NO}_{\mathrm{x}}$ concentrations are significantly lower in this experi- ment, $\mathrm{OH}$ concentrations are also lower, and methane destruction is reduced. If methane concentration was a free variable, and methane emissions were kept fixed, then clearly methane concentrations would rise in response to the lower $\mathrm{OH}$. It is this level that methane would rise to - the equilibrium methane concentration - that we wish to estimate for each experiment. Because methane needs to be adjusted, and it is an ozone precursor, we also need to estimate the ozone adjustment that would occur as a consequence of the methane adjustment.

The equilibrium methane concentration can be estimated by using the methane lifetime diagnosed from each attribution experiment, as although the methane concentration is fixed, the methane lifetime $(\tau)$ does respond, as $\mathrm{OH}$ concentrations, and hence the flux through the $\mathrm{CH}_{4}+\mathrm{OH}$ reaction, changes. We can calculate equilibrium methane concentrations, $\left[\mathrm{CH}_{4}\right]_{\mathrm{eq}}$, using:

$\left[\mathrm{CH}_{4}\right]_{\text {eq }}=\left[\mathrm{CH}_{4}\right]_{\text {base }}\left(\tau_{\text {att }} / \tau_{\text {base }}\right)^{\mathrm{f}}$

where the subscript "base" refers to the base year 2000s experiment, and the subscript "att" refers to the attribution experiment, and " $\mathrm{f}$ " is the model's $\mathrm{CH}_{4}-\mathrm{OH}$ feedback factor (Prather, 1996). Feedback factors are calculated for each model, using the base 2000s experiment (\#1) and $1850 \mathrm{CH} 4$ experiment (\#2), using:

$f=1 /(1-s)$

where

$s=\delta \ln \tau / \delta \ln \left[\mathrm{CH}_{4}\right]$

This yields the values of $f$ in Table 7 .

Equation (1) is taken from Fiore et al. (2009), and is also used in West et al. (2007) (NB it appears in the Supplement of this latter paper in an incorrect form, with the ratio of lifetimes inverted); its scientific basis originates in Fuglestvedt et al. (1999). Methane lifetimes are for the whole atmosphere; we use diagnosed tropospheric lifetimes (with respect to $\mathrm{OH}$ ) (Naik et al., 2012), and adjust to include losses in the stratosphere (120 yr lifetime) and soils (160 yr lifetime) (Table 7). 
Table 7. Methane adjustment factors ( $f$, dimensionless), whole-atmosphere lifetimes ( $\tau$, yr), from attribution experiments, and corresponding equilibrium methane concentrations (ppb), calculated using Eq. (1), for experiments \#2-5. For experiments \#0-1, we show observed imposed methane values.

\begin{tabular}{|c|c|c|c|c|c|c|c|c|c|c|c|c|c|}
\hline \multirow[b]{2}{*}{ Model } & \multirow[b]{2}{*}{$f$} & \multirow[t]{2}{*}{$\# 0$} & $1850 \mathrm{~s}$ & $\# 1$ & $2000 \mathrm{~s}$ & $\# 2$ & $1850 \mathrm{CH} 4$ & \multicolumn{2}{|c|}{$\begin{array}{ll}\# 3 & 1850 \mathrm{NO}_{\mathrm{x}} \\
\end{array}$} & \multicolumn{2}{|c|}{$\begin{array}{ll}\# 4 & 1850 \mathrm{CO}\end{array}$} & \multicolumn{2}{|c|}{ \#5 1850NMVOC } \\
\hline & & & {$\left[\mathrm{CH}_{4}\right]$} & $\tau$ & {$\left[\mathrm{CH}_{4}\right]$} & $\tau$ & {$\left[\mathrm{CH}_{4}\right]_{\mathrm{eq}}$} & $\tau$ & {$\left[\mathrm{CH}_{4}\right]_{\mathrm{eq}}$} & $\tau$ & {$\left[\mathrm{CH}_{4}\right]_{\mathrm{eq}}$} & $\tau$ & {$\left[\mathrm{CH}_{4}\right]_{\mathrm{ec}}$} \\
\hline B & 1.28 & 8.06 & 791 & 8.70 & 1751 & 7.31 & 698 & 11.60 & 2531 & 8.14 & 1606 & 8.61 & 1727 \\
\hline $\mathrm{J}$ & 1.28 & 9.02 & 791 & 9.29 & 1751 & 7.80 & 657 & 12.02 & 2435 & 8.70 & 1610 & 9.29 & 1752 \\
\hline $\mathrm{N}$ & 1.35 & 9.26 & 791 & 8.11 & 1751 & 6.62 & 504 & 12.06 & 2983 & 7.49 & 1572 & 7.82 & 1665 \\
\hline $\mathrm{O}$ & 1.28 & 8.47 & 791 & 8.06 & 1751 & 6.76 & 592 & 10.83 & 2561 & 7.68 & 1646 & 7.99 & 1734 \\
\hline $\mathrm{P}$ & 1.23 & 12.29 & 791 & 11.61 & 1751 & 9.99 & 612 & 16.38 & 2678 & 10.74 & 1591 & 11.09 & 1655 \\
\hline Q & 1.32 & 8.55 & 791 & 8.65 & 1751 & 7.13 & 622 & 13.15 & 3045 & 8.01 & 1580 & 8.16 & 1621 \\
\hline
\end{tabular}

Application of Eq. (1) yields equilibrium methane concentrations for the $\mathrm{NO}_{\mathrm{x}}, \mathrm{CO}$ and $\mathrm{NMVOC}$ attribution experiments.

The methane attribution experiment (\#2: 1850CH4) has to be treated somewhat differently, since the prescribed methane concentration (791 ppb) is appropriate for $1850 \mathrm{OH}$ conditions in the "All 1850s" experiment (\#0). We can calculate an equilibrium methane concentration for this experiment in a similar manner to the $\mathrm{NO}_{\mathrm{x}}$ experiment described above by using Eq. (1) where $\tau_{\text {att }}$ is now the methane lifetime in experiment \#2 and $\tau_{\text {base }}$ is the methane lifetime in experiment \#0. This yields an equilibrium methane concentration (e.g., $698 \mathrm{ppb}$ for model B, see Table 7) for the situation of 1850 methane emissions with 2000 emissions of $\mathrm{NO}_{\mathrm{x}}, \mathrm{CO}$ and NMVOC.

Differences between these equilibrium methane concentrations and the observed year 2000s value were used to calculate a methane radiative forcing associated with attribution experiments \#2-5. Methane RFs were calculated using global mean methane concentrations and the simple formula given by Myhre et al. (1998; their Table 3).

The methane adjustments will also generate further ozone changes and radiative forcings. We calculate these using the relationship between ozone and methane found in each model's methane experiment. Wild et al. (2012) have quantified a small non-linearity in this relationship using model experiments performed as part of the Hemispheric Transport of Air Pollution (HTAP) project. We estimate the change in ozone associated with the adjustment of methane to equilibrium using this Wild et al. (2012) relationship.

For example, for model $\mathrm{B}$, the $\mathrm{NO}_{\mathrm{x}}$ experiment (\#3) yields a methane lifetime of $11.60 \mathrm{yr}$, compared to the base year 2000s experiment (\#1) value of $8.70 \mathrm{yr}$ (Table 7). The longer lifetime reflects lower levels of $\mathrm{OH}$ due to the removal of $\mathrm{NO}_{\mathrm{x}}$ emissions. If this experiment had been carried out with methane free to adjust, Eq. (1) indicates that methane would have responded by increasing from $1751 \mathrm{ppb}$ to an equilibrium level of $2531 \mathrm{ppb}$ (Table 7), generating a radiative forcing of $261 \mathrm{~mW} \mathrm{~m}^{-2}$. Thus the methane radiative forcing associated with $\mathrm{NO}_{\mathrm{x}}$ emission increases from the 1850s up to the $2000 \mathrm{~s}$ is $-261 \mathrm{~mW} \mathrm{~m}^{-2}$ (Table 8 ). The associated ex-

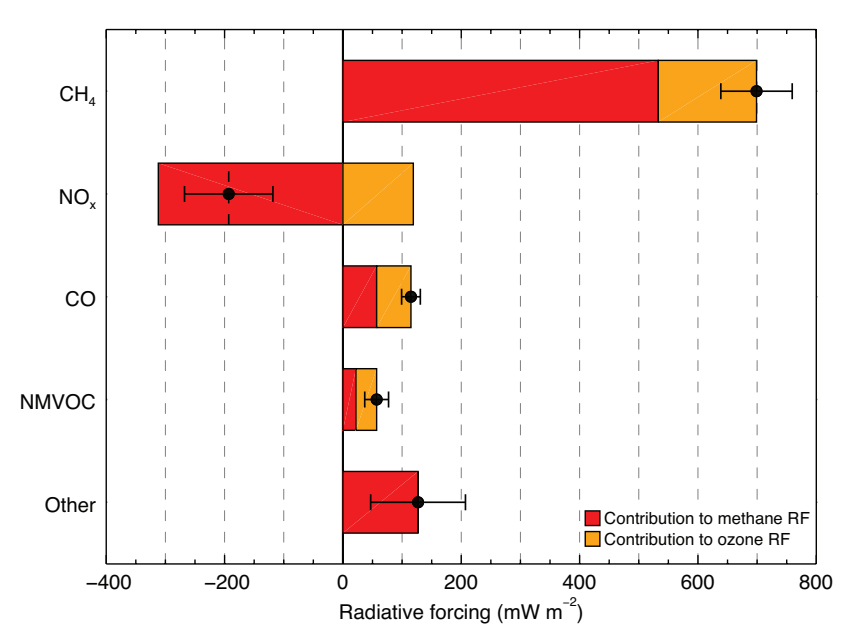

Fig. 4. Radiative forcings $\left(1850-2000, \mathrm{~mW} \mathrm{~m}^{-2}\right)$ generated by emissions of methane, $\mathrm{NO}_{\mathrm{x}}, \mathrm{CO}, \mathrm{NMVOC}$, and the interactions between these emissions ("Other"), split into their methane and ozone components. Dots are the net RF for each emission, with error bars estimated from the individual uncertainties listed in Tables 10 and 11.

tra ozone forcing is $-96 \mathrm{~mW} \mathrm{~m}^{-2}$. Adding this to the ozone forcing found directly from the $\mathrm{NO}_{\mathrm{x}}$ attribution experiment $\left(193 \mathrm{~mW} \mathrm{~m}^{-2}\right.$ ) yields a net ozone forcing of $97 \mathrm{~mW} \mathrm{~m}^{-2}$ for model B (Table 8).

We extend our analysis to include the impacts of $\mathrm{CH}_{4}, \mathrm{CO}$ and NMVOC emissions on $\mathrm{CO}_{2}$ concentrations. All these emissions oxidise to form $\mathrm{CO}_{2}$ and therefore generate an additional RF (Table 9 and Supplement). Other effects, such as impacts of methane on stratospheric $\mathrm{H}_{2} \mathrm{O}$, or impacts of changes in oxidants on secondary aerosol (Shindell et al., 2009), are not included in our analysis. We summarise the average results of all the models that ran the attribution experiments in Table 9.

The calculated RF for a change in methane concentration of 791 to $1751 \mathrm{ppb}$ (i.e. the observed and prescribed methane change between the $1850 \mathrm{~s}$ and the $2000 \mathrm{~s}$ ) is $427 \mathrm{~mW} \mathrm{~m}^{-2}$. This change in methane concentration has been produced 
Table 8. Tropospheric ozone and methane radiative forcings $\left(\mathrm{mW} \mathrm{m}^{-2}\right)$ for each model and attribution experiments \#2-5 relative to experiment \#1 (year 2000s). For methane radiative forcings in experiments \#2-5, an equilibrium $\left[\mathrm{CH}_{4}\right]$ is calculated based on the diagnosed perturbation to the methane lifetime (Table 7); the RF is then calculated from the difference between the prescribed and equilibrium methane concentrations. For ozone radiative forcings, three numbers are given: the uppermost is the RF from the calculated ozone field (e.g., Fig. S5); the middle value is the inferred ozone RF associated with the methane adjustment to equilibrium; the lower number is the net ozone RF.

\begin{tabular}{|c|c|c|c|c|c|c|c|c|}
\hline \multirow[b]{2}{*}{ Model } & \multicolumn{2}{|c|}{$\# 2.1850 \mathrm{CH}_{4}$} & \multicolumn{2}{|c|}{$\# 3.1850 \mathrm{NO}_{\mathrm{x}}$} & \multicolumn{2}{|c|}{ \#4. 1850CO } & \multicolumn{2}{|c|}{ \#5. 1850NMVOC } \\
\hline & $\mathrm{O}_{3} \mathrm{RF}$ & $\mathrm{CH}_{4} \mathrm{RF}$ & $\mathrm{O}_{3} \mathrm{RF}$ & $\mathrm{CH}_{4} \mathrm{RF}$ & $\mathrm{O}_{3} \mathrm{RF}$ & $\mathrm{CH}_{4} \mathrm{RF}$ & $\mathrm{O}_{3} \mathrm{RF}$ & $\mathrm{CH}_{4} \mathrm{RF}$ \\
\hline \multirow{3}{*}{ B } & 153 & \multirow{3}{*}{480} & 193 & \multirow{3}{*}{-261} & 38 & \multirow{3}{*}{55} & 37 & \multirow{3}{*}{9} \\
\hline & 17 & & -96 & & 21 & & 3 & \\
\hline & 170 & & 97 & & 59 & & 40 & \\
\hline \multirow{3}{*}{$\mathrm{J}$} & 103 & \multirow{3}{*}{505} & 178 & \multirow{3}{*}{-231} & 29 & \multirow{3}{*}{53} & 29 & \multirow{3}{*}{0} \\
\hline & 16 & & -58 & & 13 & & 0 & \\
\hline & 119 & & 120 & & 42 & & 29 & \\
\hline \multirow{3}{*}{$\mathrm{N}$} & 168 & \multirow{3}{*}{606} & 253 & \multirow{3}{*}{-393} & 48 & \multirow{3}{*}{68} & 15 & \multirow{3}{*}{32} \\
\hline & 58 & & -154 & & 28 & & 13 & \\
\hline & 226 & & 99 & & 76 & & 28 & \\
\hline \multirow{3}{*}{$\mathrm{O}$} & 153 & \multirow{3}{*}{546} & 205 & \multirow{3}{*}{-270} & 36 & \multirow{3}{*}{39} & 42 & \multirow{3}{*}{6} \\
\hline & 36 & & -99 & & 15 & & 2 & \\
\hline & 189 & & 106 & & 51 & & 44 & \\
\hline \multirow{3}{*}{$\mathrm{P}$} & 85 & \multirow{3}{*}{533} & 246 & \multirow{3}{*}{-305} & 35 & \multirow{3}{*}{61} & 38 & \multirow{3}{*}{36} \\
\hline & 18 & & -62 & & 13 & & 8 & \\
\hline & 103 & & 184 & & 48 & & 46 & \\
\hline \multirow{3}{*}{ Q } & 155 & \multirow{3}{*}{526} & 252 & \multirow{3}{*}{-410} & 45 & & 6 & \\
\hline & 31 & & -147 & & 25 & 65 & 19 & 49 \\
\hline & 186 & & 105 & & 70 & & 25 & \\
\hline & 136 & & 221 & & 39 & & 28 & \\
\hline Mean BJNOPQ & 30 & 533 & -102 & -312 & 19 & 57 & 8 & 22 \\
\hline & 166 & & 119 & & 58 & & 35 & \\
\hline
\end{tabular}

by the combined increases in emissions of $\mathrm{CH}_{4}, \mathrm{NO}_{\mathrm{x}}, \mathrm{CO}$ and NMVOCs. However, the sum of the RFs generated when these emissions are changed one at a time is only $300 \mathrm{~mW} \mathrm{~m}^{-2}$ (Table 9). The remaining $127 \mathrm{~mW} \mathrm{~m}^{-2}$ is due to non-linear interactions between species in the chemistry models, in particular the effect of $\mathrm{NO}_{\mathrm{x}}$ changes on the methane forcing is much larger when applied at 2000 s methane levels compared to 1850 s methane levels. The nonlinearity of the radiative forcing calculations (square root dependence) acts in the opposite direction, tending to reduce the impact of $\mathrm{NO}_{\mathrm{X}}$ changes.

For ozone RF, the non-linear interactions between emissions appear to be minor, as the linear sum of the ozone RFs from the $\mathrm{CH}_{4}, \mathrm{NO}_{\mathrm{x}}, \mathrm{CO}$ and $\mathrm{NMVOC}$ experiments is equal to the ozone RF for 1850-2000 (Table 9). Table 9 reports this for the mean of the six models, but the same linearity is also approximately found for individual models. Based on the six models that performed the attribution experiments, the mean percentage contributions to ozone RF are methane (44\%), nitrogen oxides $(31 \%)$, carbon monoxide $(15 \%)$, non-methane volatile organic compounds $(9 \%)$ (Table 10$)$. The values found here are compared with the earlier work of Shindell et al. (2005, 2009) in Tables 10 (ozone) and 11 (methane).

As can be seen in Tables 10 and 11, there are some differences between this work and the two Shindell et al. studies. For the tropospheric ozone RF, we find a smaller (but still dominant) contribution from methane emissions (the Shindell et al. (2005) result is within the range found in the ACCMIP analysis), and a larger contribution from $\mathrm{NO}_{\mathrm{x}}$ emissions. The contributions from $\mathrm{CO}$ and NMVOC emissions are less important, and more similar to the two Shindell et al. studies. For methane RF, all the studies find a rather similar contribution from methane emissions, and also from the $\mathrm{CO}$ and NMVOC emissions. However, the ACCMIP models have a more strongly negative contribution from $\mathrm{NO}_{\mathrm{x}}$ emissions, and they show a significant non-linearity in that the net effect of all emissions does not sum to give the same RF as all emissions together. The emissions based RFs are summarised in Fig. 4. 


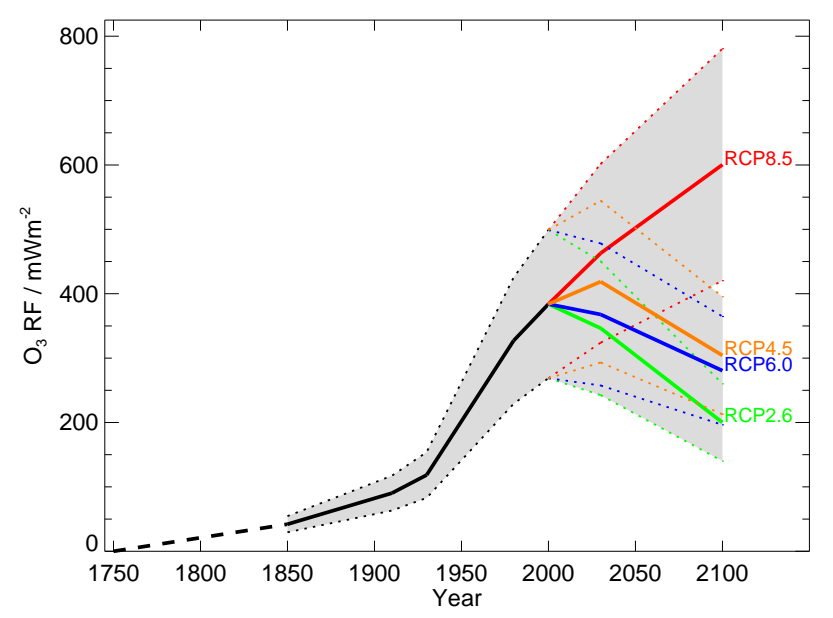

Fig. 5. Evolution of tropospheric ozone RF $\left(\mathrm{mW} \mathrm{m}^{-2}\right), 1750-2100$. For 1750-1850, we show the estimate of Skeie et al. (2011). For 1850-2000 (black line), we show MMM values for all available ACCMIP timeslices. For 2000-2100, the four RCP scenarios are shown in different colours, using values at 2030 and 2100 only. Estimated uncertainties of $\pm 30 \%$ on all values are indicated by the grey shading, bounded by dotted coloured lines. Values have been scaled to the average of the MASKZMT and MASK150 tropopauses, and the three radiation schemes used (Edwards-Slingo, Oslo, and NCAR).

\subsection{Other simulations}

Several models ran time slice simulations covering several intervening decades between the 1850s and 2000s, and also for the four future Representative Concentration Pathway scenarios (RCP2.6, RCP4.5, RCP6.0 and RCP8.5) (Table 1). Young et al. (2013) provide details of the changes in surface and tropospheric ozone from these simulations. Here, we use spatially resolved annual mean changes in tropospheric column ozone, and convolve these together with individual model's normalised ozone RFs (Fig. S2), to estimate the RF for each timeslice experiment relative to the 1850s (Fig. 5). A subset of these results (for the 1980s, 2000s, 2030s and 2100s) is also presented in Table 12. Seasonal variations in both column changes and normalised RFs are not accounted for, and this indirect method of calculating RFs also assumes that the normalised ozone RF for 1850s-2000s does not change with time; i.e. that the shape of the change in ozone vertical profile is temporally invariant. We consider that these approximations introduce only small errors in the estimates of ozone RF presented in Fig. 5 and Table 12.

Table 12 also shows mean values for selected time periods, constructed in three different ways: (i) using all available models for a given time slice; (ii) just using the four models $(\mathrm{F}, \mathrm{G}, \mathrm{K}$ and $\mathrm{N})$ that ran all of the timeslices in Table 12; and (iii) using a subset of ten models (A, B, F, G, K, $\mathrm{L}, \mathrm{M}, \mathrm{N}, \mathrm{O}$ and $\mathrm{P}$ ) that ran all the time slices except those for RCP4.5 and RCP6.0. Comparing the mean values calculated by these different methods shows that there is little
Table 9. Emission-based RFs (for 1850s-2000s) (via changes in $\mathrm{CO}_{2}, \mathrm{CH}_{4}$ and tropospheric ozone) for emitted $\mathrm{CH}_{4}, \mathrm{NO}_{\mathrm{x}}, \mathrm{CO}$, and NMVOC, based on the mean response of the six models that conducted the attribution experiments (cf. IPCC-AR4 Table 2.13).

\begin{tabular}{lrrrr}
\hline & \multicolumn{4}{c}{ Radiative forcing $\left(\mathrm{mW} \mathrm{m}^{-2}\right)$ via: } \\
\cline { 2 - 5 } Emission & $\mathrm{CO}_{2}$ & $\mathrm{CH}_{4}$ & $\mathrm{O}_{3}$ & $\mathrm{CO}_{2}+\mathrm{CH}_{4}+\mathrm{O}_{3}$ \\
\hline $\mathrm{CH}_{4}$ & 18 & 533 & 166 & 717 \\
$\mathrm{NO}_{\mathrm{x}}$ & & -312 & 119 & -193 \\
$\mathrm{CO}$ & 87 & 57 & 58 & 202 \\
NMVOC & 33 & 22 & 35 & 90 \\
Other factors & & 127 & 0 & 127 \\
Total: & 138 & $427^{\mathrm{a}}$ & $378^{\mathrm{b}}$ & 943 \\
\hline
\end{tabular}

a The total methane $\mathrm{RF}$ is constrained to be $427 \mathrm{~mW} \mathrm{~m}^{-2}$ by the observed increase in $\mathrm{CH}_{4}$ concentrations from the $1850 \mathrm{~s}(791 \mathrm{ppb})$ to $2000 \mathrm{~s}(1751 \mathrm{ppb})$, as prescribed in the models. This is then used with the other components to infer the RF due to "other factors $\mathrm{c}$ "

$\left(127=427-533+312-57-22 \mathrm{~mW} \mathrm{~m}^{-2}\right)$.

${ }^{\mathrm{b}}$ The mean value for these models for the total $\mathrm{O}_{3} \mathrm{RF}$ for $1850 \mathrm{~s}-2000 \mathrm{~s}$ is $378 \mathrm{~mW} \mathrm{~m}^{-2}$, which indicates that no other factors are required to explain the $\mathrm{O}_{3} \mathrm{RF}$.

c The "other factors" not estimated in our attribution experiments include: (i) non-linear interactions between emissions (i.e. simple linear addition of the effects of individual species misses interactions that occur when species change together); and (ii) changes in the value of $f$ between the $1850 \mathrm{~s}$ and 2000 s.

influence on the overall results (the maximum deviation is $24 \mathrm{~mW} \mathrm{~m}^{-2}$, or $\sim 10 \%$, for RCP6.0 in 2100) of the variable model coverage of different timeslices.

\subsection{Experiments that isolate the climate change component}

Most models performed the core 1850s and 2000s experiments with driving climates appropriate for these decades (Table 1). In addition, 10 models carried out sensitivity experiments with 2000s emissions, but driven by 1850 s climate. Most of these models also performed similar experiments, but driven by 2030s and 2100s climates (RCP8.5). By comparing runs with the same emissions, but different climates, we can diagnose the impact of climate change on tropospheric ozone. Figure 6 shows the impact of climate change on ozone, for the multi-model mean of the eight models that performed all of the above experiments. Figure S7 shows results for individual models.

Modelled tropospheric ozone shows a range of responses to climate change. The largest overall response is seen in models $\mathrm{G}$ and $\mathrm{H}$ (the two GISS versions), where climate change is the main driver of the $\mathrm{SH}$ decreases in ozone seen in these models (Fig. S1). In these GISS integrations, the stratosphere also changes, so it is unclear if it is stratospheric change or climate change that is driving the SH decreases. The other model with large decreases in SH ozone (M), also changes its stratosphere in its climate change experiments, however the climate change experiment does not produce the large SH decrease seen in the standard 1850s- 
Table 10. Contributions of emissions of $\mathrm{CH}_{4}, \mathrm{NO}_{\mathrm{x}}, \mathrm{CO}$ and $\mathrm{NMVOC}$ to the $1850-2000 \mathrm{O}_{3} \mathrm{RF}$, in both absolute terms (mW $\mathrm{m}^{-2}$ ) and as percentages, for this study, and also from Shindell et al. (2005, 2009). The Shindell et al. (2005, 2009) values are all for 1750-2000, and are instantaneous RFs calculated using a different methodology. The ACCMIP values are the means and standard deviations of the six models in Table 8. The Shindell et al. (2005) values have estimated errors of $\pm 20 \%$ for $\mathrm{CH}_{4}$ and $\pm 50 \%$ for other emissions.

\begin{tabular}{|c|c|c|c|}
\hline \multicolumn{4}{|c|}{ Model range of emission contributions to tropospheric $\mathrm{O}_{3} \mathrm{RF}$} \\
\hline Emission & ACCMIP & Shindell et al. (2005) & Shindell et al. (2009) \\
\hline $\mathrm{CH}_{4}$ & $166 \pm 46 \mathrm{~mW} \mathrm{~m}^{-2}(44 \pm 12 \%)$ & $200 \pm 40 \mathrm{~mW} \mathrm{~m}^{-2}(51 \pm 10 \%)$ & $275 \mathrm{~mW} \mathrm{~m}^{-2}(74 \%)$ \\
\hline $\mathrm{NO}_{\mathrm{x}}$ & $119 \pm 33 \mathrm{~mW} \mathrm{~m}^{-2}(31 \pm 9 \%)$ & $60 \pm 30 \mathrm{~mW} \mathrm{~m}^{-2}(15 \pm 8 \%)$ & $41 \mathrm{~mW} \mathrm{~m}^{-2}(11 \%)$ \\
\hline $\mathrm{CO}$ & $58 \pm 13 \mathrm{~mW} \mathrm{~m}^{-2}(15 \pm 3 \%)$ & - & $48 \mathrm{~mW} \mathrm{~m}^{-2}(13 \%)$ \\
\hline NMVOC & $35 \pm 9 \mathrm{~mW} \mathrm{~m}^{-2} \quad(9 \pm 2 \%)$ & - & $7 \mathrm{~mW} \mathrm{~m}^{-2}(2 \%)$ \\
\hline $\mathrm{CO}+\mathrm{NMVOC}$ & $93 \pm 10 \mathrm{~mW} \mathrm{~m}^{-2} \quad(25 \pm 3 \%)$ & $130 \pm 65 \mathrm{~mW} \mathrm{~m}^{-2}(33 \pm 17 \%)$ & $55 \mathrm{~mW} \mathrm{~m}^{-2}(15 \%)$ \\
\hline
\end{tabular}

Table 11. Contributions of emissions of $\mathrm{CH}_{4}, \mathrm{NO}_{\mathrm{x}}, \mathrm{CO}$ and NMVOC to the $1850-2000 \mathrm{CH}_{4} \mathrm{RF}$ ( $\mathrm{mW} \mathrm{m}^{-2}$ ), for this study, and also from Shindell et al. (2005, 2009). The Shindell et al. (2005, 2009) values are all for 1750-2000, and were calculated with a different methodology. The ACCMIP values are the means and standard deviations of the six models in Table 8. The Shindell et al. (2005) values have estimated errors of $\pm 20 \%$ for $\mathrm{CH}_{4}$ and $\pm 50 \%$ for other emissions.

\begin{tabular}{lrrr}
\hline \multicolumn{4}{c}{ Model range of emission contributions to $\mathrm{CH}_{4} \mathrm{RF}_{\left(\mathrm{mW} \mathrm{m}^{-2}\right)}$} \\
\hline Emission & ACCMIP & Shindell et al. (2005) & Shindell et al. (2009) \\
\hline $\mathrm{CH}_{4}$ & $533 \pm 39$ & $590 \pm 120$ & 530 \\
$\mathrm{NO}_{\mathrm{x}}$ & $-312 \pm 67$ & $-170 \pm 85$ & -130 \\
$\mathrm{CO}$ & $57 \pm 9$ & - & - \\
$\mathrm{NMVOC}$ & $22 \pm 18$ & - & - \\
$\mathrm{CO}+\mathrm{NMVOC}$ & $79 \pm 26$ & $80 \pm 40$ & 80 \\
\hline
\end{tabular}

2000s experiment, so the origin of this signal in this model remains unclear. Some models show increases in tropical mid- to upper tropospheric ozone, with these increases centred over the continents $(\mathrm{G}, \mathrm{H}$, and to a lesser extent $\mathrm{O}, \mathrm{F}$ and L). All these models (except F) show (small) increases in lightning $\mathrm{NO}_{\mathrm{x}}$ emissions (Table 2); however, other models that also show increases in lightning do not show obvious increases in tropical ozone (A, M, N and P). Most of the models show decreases in ozone, particularly in the tropical lower troposphere, which would be expected due to increases in water vapour and hence ozone destruction (e.g., Johnson et al., 2001; Doherty et al., 2013). Several models also show indications of increases in the stratospheric source of ozone, e.g., in the sub-tropical jet region (A, F, I, L, and P). Similar features have been seen in some future simulations under climate change scenarios (e.g., Zeng and Pyle, 2003; Stevenson et al., 2006; Kawase et al., 2011). On average, the net impact of climate change on ozone is a small decrease in tropospheric ozone burden.

The net impact of climate change on tropospheric ozone $\mathrm{RF}$ is reported in Table 12. The multi-model mean suggests that the forcing is small and negative $\left(-20\right.$ to $\left.-30 \mathrm{~mW} \mathrm{~m}^{-2}\right)$, for both the present-day and in the future, i.e. there is a small negative climate feedback related to tropospheric ozone. This feedback is rather uncertain however, with some models indicating small positive feedbacks, and others showing the sign of the feedback changing from negative for 1850 up to present day to positive for the future. These differences appear to mainly reflect competition between the mechanisms outlined above.

\section{Discussion and conclusions}

With the MASKZMT tropopause, we find a mean value for the tropospheric ozone radiative forcing (1850s-2000s) of $356 \mathrm{~mW} \mathrm{~m}^{-2}$, with a standard deviation across 17 models of $\pm 58 \mathrm{~mW} \mathrm{~m}^{-2}( \pm 16 \%)$ (Table 12). The median model has a value of $371 \mathrm{~mW} \mathrm{~m}^{-2}$, and the full range spans $211-429 \mathrm{~mW} \mathrm{~m}^{-2}$. The model at the low end of this range (model $M$ ) is an isolated outlier - the next lowest value is $297 \mathrm{~mW} \mathrm{~m}^{-2}$ (Table 12). Using an alternate tropopause (MASK150), we find slightly higher values: $377 \pm 65 \mathrm{~mW} \mathrm{~m}^{-2}( \pm 17 \%)$ (Table 3$)$. Values from the two sets of calculations differ by $6 \%$; this suggests that tropopause definition introduces an uncertainty of at least $\pm 3 \%$.

These values were calculated by the Edwards and Slingo (1996) (E-S) radiation scheme. We find that the E-S radiation scheme gives net, stratospherically adjusted ozone RFs that are $10 \%$ higher than comparable schemes from Oslo and NCAR (Table 5). Taking the mean of our values 
Table 12. Tropospheric ozone RFs $\left(\mathrm{mW} \mathrm{m}^{-2}\right.$ ) relative to the 1850 s (for MASKZMT), calculated from column ozone changes and normalised RFs for each model. Values shown for some models in brackets under 2000s and for the RCP8.5 scenario are the impact of climate change on RF, with mean $( \pm S D)$ values given in the last row. NB values for 2000 s differ very slightly from Table 3 due to the masking of some normalised RF values.

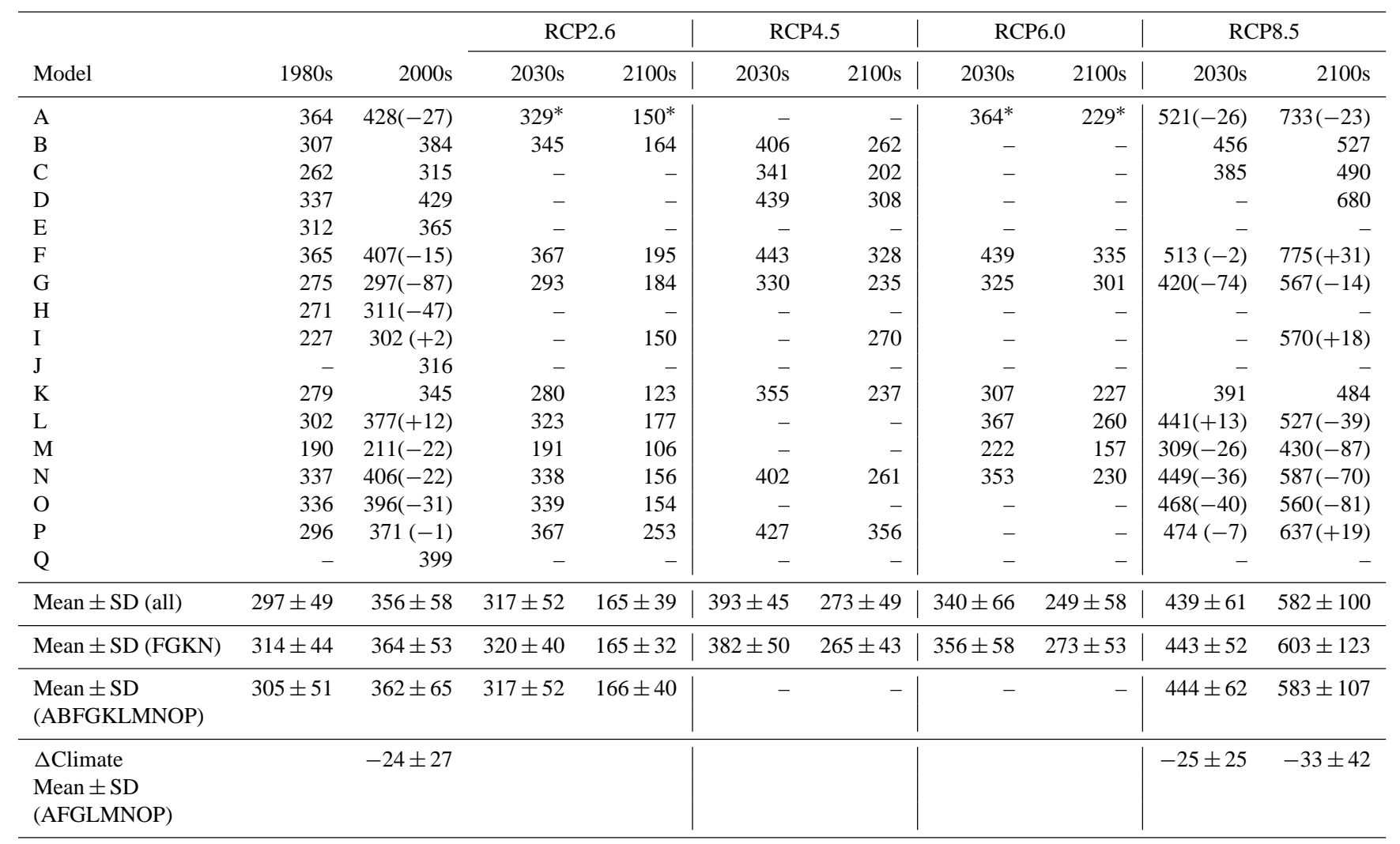

* Model A (CESM-CAM-superfast) RCP2.6 and 6.0 results used SST/SIC inconsistent with these scenarios.

for the two different tropopauses with the E-S scheme $\left(367 \mathrm{~mW} \mathrm{~m}^{-2}\right)$, and adjusting for the Oslo and NCAR schemes producing slightly lower values (i.e. giving equal weight to each radiation scheme by multiplying by a factor of $(1.0+0.9+0.9) / 3=0.93)$, our best estimate of tropospheric ozone RF (1850-2000) is $343 \mathrm{~mW} \mathrm{~m}^{-2}$.

Based on a comparison of instantaneous clear sky SW ozone RFs between the E-S and Oslo schemes (Table 5), we estimate radiative transfer schemes introduce uncertainty of about $\pm 6 \%$. Clouds influence ozone RFs to different degrees in the E-S and Oslo schemes, and add uncertainty of at least $\pm 7 \%$ (Table 4). The influence of stratospheric adjustment also varies between the two schemes, adding uncertainty of about $\pm 3 \%$. Based on these individual uncertainties, and assuming they are independent, we estimate an overall uncertainty associated with the radiation scheme of about $\pm 10 \%$, based on the square root of the sum of the squares (RSS). Combining these uncertainties with the model range $( \pm 17 \%)$ and difference due to tropopause definition $( \pm 3 \%)$, we estimate an overall (RSS) uncertainty of $\pm 20 \%$ from these factors.
Further sources of uncertainty in the ozone RF stem from uncertainties in precursor emissions (natural and anthropogenic), as well as changes in climate and stratospheric ozone. The partitioning of RF between tropospheric and stratospheric ozone may also change as tropopause height and morphology changes (Wilcox et al., 2012); we have not explicitly considered this impact on RF. Most models predict relatively small impacts on tropospheric ozone via climate change up to present-day, but these impacts may increase in future (Fig. S7). Uncertainties associated with these factors, and emissions in particular, are probably similar or larger than the $\pm 20 \%$ estimated above. We therefore estimate an overall uncertainty of $\pm 30 \%$ on our central estimate (Skeie et al. (2011) estimate the same value for uncertainty). Given the magnitude of the uncertainty, we quote values to two significant figures, giving our best estimate and uncertainty of $340 \pm 100 \mathrm{~mW} \mathrm{~m}^{-2}$. It should be noted that this value is for 1850 s to 2000 s (which we take to be 1850 to 2000). Skeie et al. (2011) calculated tropospheric ozone increases between 1750 and 1850 of $1.0 \mathrm{DU}$ (using model B), suggesting an extra $42 \mathrm{~mW} \mathrm{~m}^{-2}$ should be added to give the RF from 1750 to 2000. Similarly, they calculate an increase from 2000 to 2010 
of $0.5 \mathrm{DU}$, which would add a further $21 \mathrm{~mW} \mathrm{~m}^{-2}$. Hence for 1750-2010 our best estimate of tropospheric ozone RF is 42 $+343+21=406$, or, quoted to two significant figures: $410 \pm 120 \mathrm{~mW} \mathrm{~m}^{-2}$.

While it is well understood that increases in $\mathrm{CH}_{4}, \mathrm{NO}_{\mathrm{x}}$, $\mathrm{CO}$ and NMVOCs have driven up tropospheric ozone, only one model has previously explored the relative contributions of these different precursors (Shindell et al., 2005, 2009). Applying six different models here, we estimate that $\mathrm{CH}_{4}, \mathrm{NO}_{\mathrm{x}}, \mathrm{CO}$ and NMVOCs are respectively responsible for $44 \pm 12 \%$ ( \pm 1 standard deviation range), $31 \pm 9 \%$, $15 \pm 3 \%$ and $9 \pm 2 \%$ of the 1850 s-2000s ozone RF (Table 10). As can be seen from the model range, there remains some uncertainty over the exact values for these fractions; an important source of uncertainty stems from extrapolating results from the experiments to yield equilibrium methane concentrations. Model $\mathrm{P}$ is an outlier, the only model that finds $\mathrm{NO}_{\mathrm{x}}$ emissions to be a much larger driver of tropospheric ozone RF than $\mathrm{CH}_{4}$ emissions. This probably reflects model P's relatively long methane lifetime (Naik et al., 2012), which is probably related to this model's simplified representation of photolysis. These contributions compare to values of $51 \%\left(\mathrm{CH}_{4}\right), 15 \%\left(\mathrm{NO}_{\mathrm{x}}\right)$, and $33 \%(\mathrm{CO}$ and NMVOC combined) (Table 10) from Shindell et al. (2005), as reported in IPCC-AR4 (Forster et al., 2007, Table 2.13). The results from Shindell et al. (2009) indicate a split of: $74 \%\left(\mathrm{CH}_{4}\right), 11 \%\left(\mathrm{NO}_{\mathrm{x}}\right), 13 \%(\mathrm{CO})$ and $2 \%$ (NMVOCs) (Table 10), which is outside the model range (except for $\mathrm{CO})$ found in this study. The reasons for differences between the two Shindell et al. studies and the results presented here are unclear, but do point to significant model diversity and uncertainty in the drivers of tropospheric ozone increases. Using the fractions from this study, we find that for 17502010 , the tropospheric ozone RF of $410 \mathrm{~mW} \mathrm{~m}^{-2}$ can be apportioned to increased emissions as follows: $180 \mathrm{~mW} \mathrm{~m}^{-2}$ from $\mathrm{CH}_{4}, 127 \mathrm{~mW} \mathrm{~m}^{-2}$ from $\mathrm{NO}_{\mathrm{x}}, 62 \mathrm{~mW} \mathrm{~m}^{-2}$ from $\mathrm{CO}$ and $37 \mathrm{~mW} \mathrm{~m}^{-2}$ from NMVOC. By both directly increasing the methane concentration and by indirectly affecting methane's lifetime, these emissions have also influenced the methane RF, and we find values of: $533,-312,+57$ and $+22 \mathrm{~mW} \mathrm{~m}^{-2}$ for $\mathrm{CH}_{4}, \mathrm{NO}_{\mathrm{x}}, \mathrm{CO}$ and NMVOC, respectively. An additional contribution of $127 \mathrm{~mW} \mathrm{~m}^{-2}$, due to interactions between these emissions has also been inferred (Table 9). Further experiments are required to clarify interactions between which species are most important. With the exception of $\mathrm{NO}_{\mathrm{x}}$, all these emissions oxidise to form $\mathrm{CO}_{2}$ and therefore generate an additional RF (Table 9 and Supplement). There are further RF impacts of these emissions via secondary aerosol formation and changes in stratospheric water vapour that have not been estimated here (see Shindell et al., 2009). Based on their impacts on $\mathrm{CO}_{2}, \mathrm{CH}_{4}$ and tropospheric ozone, we estimate overall emissions based RFs for $\mathrm{CH}_{4}, \mathrm{NO}_{\mathrm{x}}, \mathrm{CO}$ and NMVOC of: $+717,-193,+202$ and $+90 \mathrm{~mW} \mathrm{~m}^{-2}$, respectively. A further $127 \mathrm{~mW} \mathrm{~m}^{-2}$ stems from interactions between these emissions (Table 9). The contributions of methane, $\mathrm{NO}_{\mathrm{x}}, \mathrm{CO}$ and NMVOC emissions to methane and tropospheric ozone RF are summarised in Fig. 4.

Normalising the tropospheric ozone RF by the change in tropospheric column ozone (Fig. 3d), we find a global mean value of $42 \mathrm{~mW} \mathrm{~m}^{-2} \mathrm{DU}^{-1}$ (using MASKZMT). This is similar to values from earlier studies, namely $42 \mathrm{~mW} \mathrm{~m}^{-2} \mathrm{DU}^{-1}$ (Ramaswamy et al., 2001; their Table 6.3 - a mean value from 11 studies) and $36 \mathrm{~mW} \mathrm{~m}^{-2} \mathrm{DU}^{-1}$ (Gauss et al., 2003; their Table 3 - a mean value from 11 models simulating 2000 to 2100 changes). Fry et al. (2012), using the GFDL Radiative Transfer Model (GFDL GAMDT, 2004), calculated a value of $36 \mathrm{~mW} \mathrm{~m}^{-2} \mathrm{DU}^{-1}$ based on ozone perturbations generated by emissions from the four regions (N. America, Europe, E. Asia and S. Asia) in the Hemispheric Transport of Air Pollution (HTAP) project. Whilst these regions encompass most of the world's anthropogenic emissions, the tropics are somewhat under-represented, partially explaining the slightly lower value compared to that found here (Fig. 3d). Normalised forcings vary slightly between models (Fig. S2), reflecting differing ozone changes at different latitudes and heights (Fig. S1).

Using the normalised forcing from each model, together with the simulated tropospheric column ozone change, we have calculated RFs for each model for each available timeslice, and scaled our values as described above, to take the average of the two tropopause masking methods, and the three radiation schemes (Fig. 5). Although different subsets of models ran the timeslices, we find this has only a small influence on calculated multi-model mean values (Table 12). Making the harmonisation to our best estimate of 1750s2000s RF, we estimate tropospheric ozone RFs (relative to the 1750) of 120,330 and $380 \mathrm{~mW} \mathrm{~m}^{-2}$ for 1930,1980 and 2000, respectively. For the RCP2.6 scenario, we find values of 350 and $200 \mathrm{~mW} \mathrm{~m}^{-2}$ for 2030 and 2100; for RCP4.5: 420 and $300 \mathrm{~mW} \mathrm{~m}^{-2}$; for RCP6.0: 370 and $280 \mathrm{~mW} \mathrm{~m}^{-2}$; and for RCP8.5: 460 and $600 \mathrm{~mW} \mathrm{~m}^{-2}$ (again, all relative to 1750 , see Fig. 5). All these have similar uncertainties to our pre-industrial to present-day estimate, which is at least $\pm 30 \%$. Uncertainties are arguably smaller for the future scenarios, as they are for exactly prescribed emissions; however, other sources of uncertainty increase, in particular the effects of climate change, land-use change and changing stratospheric ozone on tropospheric ozone. It must also be noted that the RCP scenarios do not fully represent the possible range of future ozone precursor emissions (van Vuuren et al., 2011). 


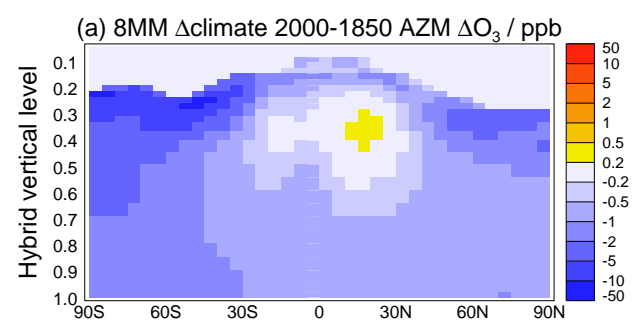

(c) $8 \mathrm{MM} \Delta$ climate $2030-1850 \mathrm{AZM} \Delta \mathrm{O}_{3} / \mathrm{ppb}$

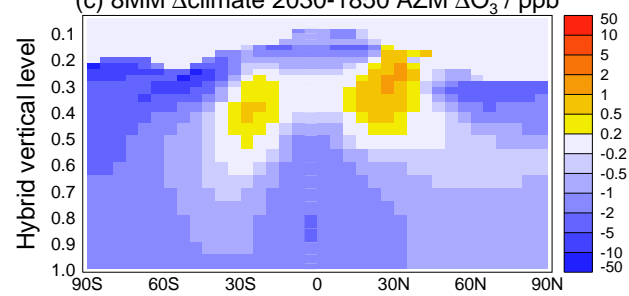

(e) $8 \mathrm{MM} \Delta$ climate $2100-1850 \mathrm{AZM} \Delta \mathrm{O}_{3} / \mathrm{ppb}$

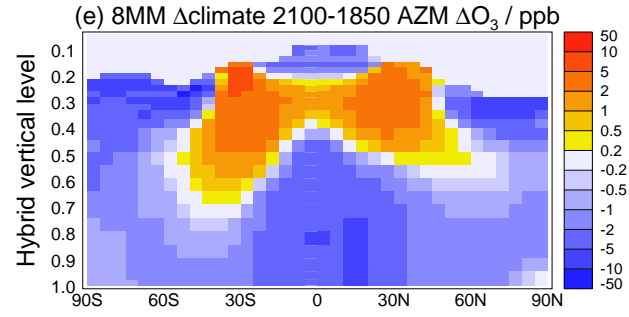

(b) $8 \mathrm{MM} \Delta$ climate $2000-1850 \mathrm{ATC} \mathrm{O}_{3}(-0.7) \mathrm{DU}$

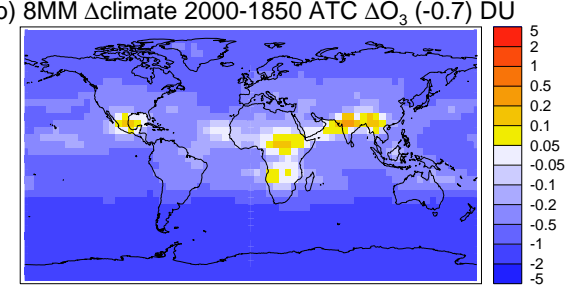

(d) $8 \mathrm{MM} \Delta$ climate $2030-1850 \mathrm{ATC}_{\Delta \mathrm{O}}(-0.6) \mathrm{DU}$

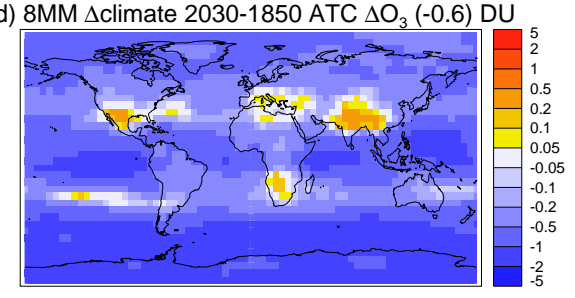

(f) $8 \mathrm{MM} \Delta$ climate $2100-1850 \mathrm{ATC} \mathrm{O}_{3}(-0.7) \mathrm{DU}$

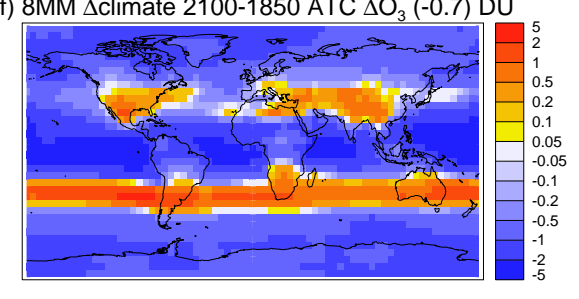

Fig. 6. Eight-model mean (8MM) responses of ozone to climate change. The eight models are A, F, G, L, M, N, O, and P. Panels (a, c, e) are AZM changes; $(\mathbf{b}, \mathbf{d}, \mathbf{f})$ are ATC changes. Panels (a, b) show changes for 2000s-1850s climate change; (c, d) for 2030s(RCP8.5)-1850s climate change; and (e, f) for 2100s(RCP8.5)-1850s climate change. Figure S7 shows equivalent plots for individual models.

Over the 1850s-2000s, climate change has had relatively small influences on tropospheric ozone in most models (Figs. 6 and S7), but is more important in some (e.g., models $\mathrm{G}$ and $\mathrm{H}$ ). In the future, models suggest these changes will generally increase, with models displaying some coherent responses (Fig. S7). All models suggest ozone in the tropical lower troposphere will reduce, mainly due to warmer temperatures and higher water vapour concentrations. Most models indicate that ozone will increase in the sub-tropical to mid-latitude upper troposphere, due to a combination of increased lightning $\mathrm{NO}_{\mathrm{x}}$ production (Schumann and Huntrieser, 2007), and an increase of stratosphere-totroposphere transport (Hegglin and Shepherd, 2009), as suggested by some earlier studies.

This study provides an up-to-date assessment of the tropospheric ozone radiative forcing included in the current generation of Earth System Models participating in CMIP5. Although the magnitudes and uncertainties in the tropospheric ozone radiative forcing are rather similar to previous assessments, this study sets a useful benchmark for future work. There remains significant diversity in model response to ozone precursor emissions and climate change, and this range of model behaviour needs to be better understood if models are to provide useful advice to policymakers. Future studies should target the key processes that control tropospheric ozone and its precursors.

\section{Supplementary material related to this article is available online at: http://www.atmos-chem-phys.net/13/ 3063/2013/acp-13-3063-2013-supplement.pdf.}

Acknowledgements. ACCMIP is organized under the auspices of Atmospheric Chemistry and Climate (AC\&C), a project of International Global Atmospheric Chemistry (IGAC) and Stratospheric Processes And their Role in Climate (SPARC) under the International Geosphere-Biosphere Project (IGBP) and World Climate Research Program (WCRP). The authors are grateful to the British Atmospheric Data Centre (BADC), which is part of the NERC National Centre for Atmospheric Science (NCAS), for collecting and archiving the ACCMIP data. D. S. thanks James Manners for assistance in setting up the E-S radiation code. GAF, STR and WJC were supported by the Joint DECC and Defra Integrated Climate Programme (GA01101) and the Defra SSNIP air quality contract AQ 0902. GZ acknowledges NIWA HPCF facility and funding from New Zealand Ministry of Science and Innovation. The CESM project is supported by the National Science Foundation and the Office of Science (BER) of the US Department of Energy. The 
National Center for Atmospheric Research is operated by the University Corporation for Atmospheric Research under sponsorship of the National Science Foundation. The work of DB and PC was funded by the US Dept. of Energy (BER), performed under the auspices of LLNL under Contract DE-AC52-07NA27344, and used the supercomputing resources of NERSC under contract No. DEAC02-05CH11231. VN and LWH acknowledge efforts of GFDL's Global Atmospheric Model Development Team in the development of the GFDL-AM3 and Modeling Services Group for assistance with data processing. The GEOSCCM work was supported by the NASA Modeling, Analysis and Prediction program, with computing resources provided by NASA's High-End Computing Program through the NASA Advanced Supercomputing Division. The MIROC-CHEM calculations were perfomed on the NIES supercomputer system (NEC SX-8R), and supported by the Environment Research and Technology Development Fund (S-7) of the Ministry of the Environment, Japan. The STOC-HadAM3 work made use of the facilities of HECToR, the UK's national high-performance computing service, which is provided by UoE HPCx Ltd at the University of Edinburgh, Cray Inc and NAG Ltd., and funded by the Office of Science and Technology through EPSRC's High End Computing Programme. The LMDz-OR-INCA simulations were done using computing resources provided by the CCRT/GENCI computer center of the CEA. The CICERO-OsloCTM2 simulations were done within the projects SLAC (Short Lived Atmospheric Components) and EarthClim funded by the Norwegian Research Council. The MOCAGE simulations were supported by Météo-France and CNRS. Supercomputing time was provided by Météo-France/DSI supercomputing center. DTS and YHL acknowledge support from the NASA MAP and ACMAP programs. D. P. would like to thank the Canadian Foundation for Climate and Atmospheric Sciences for their long-running support of CMAM development. AC was supported by the SciDAC program of the Dept. of Energy.

Finally, we acknowledge support towards publication costs from the UK Met Office, NOAA, CICERO and NIWA, in the absence of support from Edinburgh University.

Edited by: M. Dameris

\section{References}

Andersson, C. and Engardt, M.: European ozone in a future climate: Importance of changes in dry deposition and isoprene emissions, J. Geophys. Res.-Atmos., 115, D02303, doi:10.1029/2008JD011690, 2010.

Anfossi, D., Sandroni, S., and Viarengo, S.: Tropospheric ozone in the nineteenth century: the Moncalieri series, J. Geophys. Res., 96, 17349-17352, 1991.

Arneth, A., Sitch, S., Bondeau, A., Butterbach-Bahl, K., Foster, P., Gedney, N., de Noblet-Ducoudré, N., Prentice, I. C., Sanderson, M., Thonicke, K., Wania, R., and Zaehle, S.: From biota to chemistry and climate: towards a comprehensive description of trace gas exchange between the biosphere and atmosphere, Biogeosciences, 7, 121-149, doi:10.5194/bg-7-121-2010, 2010.

Berntsen, T. K., Isaksen, I. S. A., Myhre, G., Fuglestvedt, J., Stordal, F., Larsen, T., Freckleton, R., and Shine, K. P.: Effects of anthropogenic emissions on tropospheric ozone and its radiative forcing, J. Geophys. Res., 102, 28101-28126, doi:10.1029/97JD02226, 1997.

Bowman, K., Shindell, D., Worden, H., Lamarque, J. F., Young, P. J., Stevenson, D., Qu, Z., de la Torre, M., Bergmann, D., Cameron-Smith, P., Collins, W. J., Doherty, R., Dalsøren, S., Faluvegi, G., Folberth, G., Horowitz, L. W., Josse, B., Lee, Y. H., MacKenzie, I., Myhre, G., Nagashima, T., Naik, V., Plummer, D., Rumbold, S., Skeie, R., Strode, S., Sudo, K., Szopa, S., Voulgarakis, A., Zeng, G., Kulawik, S., and Worden, J.: Observational constraints on ozone radiative forcing from the Atmospheric Chemistry Climate Model Intercomparison Project (ACCMIP), Atmos. Chem. Phys. Discuss., 12, 23603-23644, doi:10.5194/acpd-12-23603-2012, 2012.

Cionni, I., Eyring, V., Lamarque, J. F., Randel, W. J., Stevenson, D. S., Wu, F., Bodeker, G. E., Shepherd, T. G., Shindell, D. T., and Waugh, D. W.: Ozone database in support of CMIP5 simulations: results and corresponding radiative forcing, Atmos. Chem. Phys., 11, 11267-11292, doi:10.5194/acp-11-11267-2011, 2011.

Cooper, O. R., Parrish, D. D., Stohl, A. Trainer, M., Nédélec, P., Thouret, V., Cammas, J. P., Oltmans, S. J., Johnson, B. J., Tarasick, D., Leblanc, T., McDermid, I. S., Jaffe, D., Gao, R., Stith, J., Ryerson T., Aikin, K., Campos, T., Weinheimer, A., and Avery, M. A.: Increasing springtime ozone mixing ratios in the free troposphere over western North America, Nature, 463, 344-348, doi:10.1038/nature08708, 2010.

Crutzen, P. J.: Photochemical reactions initiated by and influencing ozone in the unpolluted troposphere, Tellus, 26, 47-57, 1974.

Crutzen, P. J. and Zimmerman, P. H.: The changing photochemistry of the troposphere, Tellus, 43, 136-151, 1991.

Derwent, R. G., Jenkin, M. E., and Saunders, S. M.: Photochemical ozone creation potentials for a large number of reactive hydrocarbons under European conditions, Atmos. Environ., 30, 181-199, doi:10.1016/1352-2310(95)00303-G, 1996.

Doherty, R. M., Wild, O., Shindell, D. T., Zeng, G., MacKenzie, I. A., Collins, W. J., Fiore, A. M., Stevenson, D. S., Dentener, F. J., Schultz, M. G., Hess, P., Derwent, R. G., and Keating, T. J.: Impacts of climate change on surface ozone and intercontinental ozone 1 pollution: A multi-model study, J. Geophys. Res., doi:10.1029/2012JD018474, in press, 2013.

Edwards, J. M. and Slingo, A.: Studies with a flexible new radiation code. I: Choosing a configuration for a large-scale model, Q. J. Roy. Meteorol. Soc., 122, 689-719, 1996.

Engel, A., Möbius, T., Bönisch, H., Schmidt, U., Heinz, R., Levin, I., Atlas, E., Aoki, S., Nakazawa, T., Sugawara, S., Moore, F., Hurst, D., Elkins, J., Schauffler, S., Andrews, A., and Boering, K.: Age of stratospheric air unchanged within uncertainties over the past 30 years, Nature Geosci., 2, 28-31, doi:10.1038/ngeo388, 2009.

Fiore, A. M., Dentener, F. J., Wild, O., Cuvelier, C., Schultz, M. G., Hess, P., Textor, C., Schulz, M., Doherty, R. M., Horowitz, L. W., MacKenzie, I. A., Sanderson, M. G., Shindell, D. T., Stevenson, D. S., Szopa, S., Van Dingenen, R., Zeng, G., Atherton, C., Bergmann, D., Bey, I., Carmichael, G., Collins, W. J., Duncan, B. N., Faluvegi, G., Folberth, G., Gauss, M., Gong, S., Hauglustaine, D., Holloway, T., Isaksen, I. S. A., Jacob, D. J., Jonson, J. E., Kaminski, J. W., Keating, T. J., Lupu, A., Marmer, E., Montanaro, V., Park, R. J., Pitari, G., Pringle, K. J., Pyle, J. A., Schroeder, S., Vivanco, M. G., Wind, P., Wojcik, G., Wu, S., and Zuber, A.: Multi-model Estimates of Intercontinental Source- 
Receptor Relationships for Ozone Pollution, J. Geophys. Res., 114, D04301, doi:10.1029/2008JD010816, 2009.

Fiore, A. M., Naik, V., Spracklen, D. V., Steiner, A., Unger, N., Prather, M., Bergmann, D., Cameron-Smith, P. J., Cionni, I., Collins, W. J., Dalsoren, S., Eyring, V., Folberth, G. A., Ginoux, P., Horowitz, L. W., Josse, B., Lamarque, J. F., MacKenzie, I. A., Nagashima, T., O’Connor, F. M., Righi, M., Rumbold, S. T., Shindell, D. T., Skeie, R. B., Sudo, K., Szopa, S., Takemura, T., and Zeng, G.: Global air quality and climate, Chem. Soc. Rev., 41, 6663, doi:10.1039/c2cs35095e, 2012.

Fishman, J., Watson, C. E. Larsen, J. C., and Logan, J. A.: Distribution of Tropospheric Ozone Determined from Satellite Data, J. Geophys. Res., 95, 3599-3617, 1990.

Forster, P., Ramaswamy, V., Artaxo, P., Berntsen, T., Betts, R., Fahey, D. W., Haywood, J. L., J., Lowe, D. C., Myhre, G., Nganga, J., Prinn, R., Raga, G., Schulz, M., and Van Dorland, R.: Changes in atmospheric constituents and in radiative forcing, in: Climate change 2007: The physical science basis, edited by: Solomon, S., Cambridge University Press, New York, 2007.

Fowler, D., Pilegaard, K., Sutton, M. A., Ambus, P., Raivonen, M., Duyzer, J., Simpson, D., Fagerli, H., Fuzzi, S., Schjoerring, J. K., Granier, C., Neftel, A., Isaksen, I. S. A., Laj, P., Maione, M., Monks, P. S., Burkhardt, J., Daemmgen, U., Neirynck, J., Personne, E., Wichink-Kruit, R., Butterbach-Bahl, K., Flechard, C., Tuovinen, J. P., Coyle, M., Gerosa, G., Loubet, B., Altimir, N., Gruenhage, L., Ammann, C., Cieslik, S., Paoletti, E., Mikkelsen, T. N., Ro-Poulsen, H., Cellier, P., Cape, J. N., Horváth, L., Loreto, F., Niinemets, Ü., Palmer, P. I., Rinne, J., Misztal, P., Nemitz, E., Nilsson, D., Pryor, S., Gallagher, M. W., Vesala, T., Skiba, U., Brüggemann, N., Zechmeister-Boltenstern, S., Williams, J., O'Dowd, C., Facchini, M. C., de Leeuw, G., Flossman, A., Chaumerliac, N., and Erisman, J. W.: Atmospheric composition change: Ecosystems-Atmosphere interactions, Atmos. Environ., 43, 5193-5267, doi:10.1016/j.atmosenv.2009.07.068, 2009.

Fry, M. M., Naik, V., West, J. J., Schwarzkopf, M. D., Fiore, A. M., Collins, W. J., Dentener, F. J., Shindell, D. T., Atherton, C., Bergmann, D., Duncan, B. N., Hess, P., MacKenzie, I. A., Marmer, E., Schultz, M. G., Szopa, S., Wild, O., and Zeng, G.: The Influence of ozone precursor emissions from four world regions on tropospheric composition and radiative climate forcing, J. Geophysical Res., 117, D07306, doi:10.1029/2011JD017134, 2012.

Fuglestvedt, J. S., Berntsen, T. K., Isaksen, I. S. A., Mao, H., Liang, X.-Z., and Wang, W.-C.: Climatic forcing of nitrogen oxides through changes in tropospheric ozone and methane: Global model studies, Atmos. Environ., 33, 961-967, doi:10.1016/S1352-2310(98)00217-9, 1999.

Ganzeveld, L., Bouwman, L., Stehfest, E., Vuuren, D. P. V., Eickhout, B., and Lelieveld, J.: Impact of future land use and land cover changes on atmospheric chemistry-climate interactions, J. Geophys. Res., 115, D23301, doi:10.1029/2010JD014041, 2010.

Gauss, M., Myhre, G., Pitari, G., Prather, M. J., Isaksen, I. S. A., Berntsen, T. K., Brasseur, G. P., Dentener, F. J., Derwent, R. G., Hauglustaine, D. A., Horowitz, L. W., Jacob, D. J., Johnson, M., Law, K. S., Mickley, L. J., Muller, J.-F., Plantevin, P.-H., Pyle, J. A., Rogers, H. L., Stevenson, D. S., Sundet, J. K., van Weele, M., and Wild, O.: Radiative forcing in the 21 st century due to ozone changes in the troposphere and the lower stratosphere, J.
Geophys. Res., 108, 4292, doi:10.1029/2002JD002624, 2003.

Gauss, M., Myhre, G., Isaksen, I. S. A., Grewe, V., Pitari, G., Wild, O., Collins, W. J., Dentener, F. J., Ellingsen, K., Gohar, L. K., Hauglustaine, D. A., Iachetti, D., Lamarque, F., Mancini, E., Mickley, L. J., Prather, M. J., Pyle, J. A., Sanderson, M. G., Shine, K. P., Stevenson, D. S., Sudo, K., Szopa, S., and Zeng, G.: Radiative forcing since preindustrial times due to ozone change in the troposphere and the lower stratosphere, Atmos. Chem. Phys., 6, 575-599, doi:10.5194/acp-6-575-2006, 2006.

GFDL Global Atmospheric Model Development Team (GFDL GAMDT), The new GFDL global atmosphere and land model AM2-LM2: Evaluation with prescribed SST simulations, J. Climate, 17, 4641-4673, doi:10.1175/JCLI-3223.1, 2004.

Hansen, J., Sato, M., and Ruedy, R.: Radiative forcing and climate response, J. Geophys. Res., 102, 6831-6864, 1997.

Hauglustaine, D. A. and Brasseur, G. P.: Evolution of tropospheric ozone under anthropogenic activities and associated radiative forcing of climate, J. Geophys. Res., 106, 32337-32360, 2001.

Hegglin, M. I. and Shepherd, T. G.: Large climate-induced changes in ultraviolet index and stratosphere-to-troposphere ozone flux, Nature Geosci., 2, 687-691, doi:10.1038/ngeo604, 2009.

Hough, A. E. and Derwent, R. G.: Changes in the global concentration of tropospheric ozone due to human activities, Nature 344, 645-648, doi:10.1038/344645a0, 1990.

Hsu, J. and Prather, M. J.: Stratospheric variability and tropospheric ozone, J. Geophys. Res., 114, D06102, doi:10.1029/2008JD010942, 2009.

Huijnen, V., Williams, J., van Weele, M., van Noije, T., Krol, M., Dentener, F., Segers, A., Houweling, S., Peters, W., de Laat, J., Boersma, F., Bergamaschi, P., van Velthoven, P., Le Sager, P., Eskes, H., Alkemade, F., Scheele, R., Nédélec, P., and Pätz, H.-W.: The global chemistry transport model TM5: description and evaluation of the tropospheric chemistry version 3.0, Geosci. Model Dev., 3, 445-473, doi:10.5194/gmd-3-445-2010, 2010.

Isaksen, I. S. A., Granier, C., Myhre, G., Berntsen, T. K., Dalsøren, S. B., Gauss, M., Klimont, Z., Benestad, R., Bousquet, P., Collins, W., Cox, T., Eyring, V., Fowler, D., Fuzzi, S., Jockel, P., Laj, P., Lohmann, U., Maione, M., Monks, P., Prevot, A. S. H., Raes, F., Richter, A., Rognerud, B., Schulz, M., Shindell, D., Stevenson, D. S., Storelvmo, T., Wang, W.-C., van Weele, M., Wild, M., and Wuebbles, D.: Atmospheric Composition Change: Climate-Chemistry interactions, Atmos. Environ., 43, 5138-5192, doi:10.1016/j.atmosenv.2009.08.003, 2009.

Johnson, C. E., Stevenson, D. S., Collins, W. J., and Derwent, R. G.: Role of climate feedback on methane and ozone studied with a coupled Ocean-Atmosphere-Chemistry model, Geophys. Res. Lett., 28, 1723-1726, 2001.

Kawase, H., Nagashima, T., Sudo, K., and Nozawa, T.: Future changes in tropospheric ozone under Representative Concentration Pathways (RCPs), Geophys. Res. Lett., 38, L05801, doi:10.1029/2010GL046402, 2011.

Kedzie, W. K.: Ozone in Kansas Atmosphere, Transactions of the Kansas Academy of Science (1872-1880), 6, 18-25, 1877.

Lacis, A. A., Wuebbles, D. J., and Logan, J. A.: Radiative forcing of climate by changes in the vertical distribution of ozone, J. Geophys. Res., 95, 9971-9981, 1990.

Lamarque, J.-F., Hess, P., Emmons, L., Buja, L., Washington, W., and Granier, C.: Tropospheric ozone evolution between 1890 and 1990, J. Geophys. Res., 110, D08304, 
doi:10.1029/2004JD005537, 2005.

Lamarque, J.-F., Bond, T. C., Eyring, V., Granier, C., Heil, A., Klimont, Z., Lee, D., Liousse, C., Mieville, A., Owen, B., Schultz, M. G., Shindell, D., Smith, S. J., Stehfest, E., Van Aardenne, J., Cooper, O. R., Kainuma, M., Mahowald, N., McConnell, J. R., Naik, V., Riahi, K., and van Vuuren, D. P.: Historical (1850-2000) gridded anthropogenic and biomass burning emissions of reactive gases and aerosols: methodology and application, Atmos. Chem. Phys., 10, 7017-7039, doi:10.5194/acp10-7017-2010, 2010.

Lamarque, J.-F., Shindell, D. T., Josse, B., Young, P. J., Cionni, I., Eyring, V., Bergmann, D., Cameron-Smith, P., Collins, W. J., Doherty, R., Dalsoren, S., Faluvegi, G., Folberth, G., Ghan, S. J., Horowitz, L. W., Lee, Y. H., MacKenzie, I. A., Nagashima, T., Naik, V., Plummer, D., Righi, M., Rumbold, S. T., Schulz, M., Skeie, R. B., Stevenson, D. S., Strode, S., Sudo, K., Szopa, S., Voulgarakis, A., and Zeng, G.: The Atmospheric Chemistry and Climate Model Intercomparison Project (ACCMIP): overview and description of models, simulations and climate diagnostics, Geosci. Model Dev., 6, 179-206, doi:10.5194/gmd-6-179-2013, 2013.

Lee, Y. H., Lamarque, J.-F., Flanner, M. G., Jiao, C., Shindell, D. T., Berntsen, T., Bisiaux, M. M., Cao, J., Collins, W. J., Curran, M., Edwards, R., Faluvegi, G., Ghan, S., Horowitz, L. W., McConnell, J. R., Myhre, G., Nagashima, T., Naik, V., Rumbold, S. T., Skeie, R. B., Sudo, K., Takemura, T., and Thevenon, F.: Evaluation of preindustrial to present-day black carbon and its albedo forcing from ACCMIP (Atmospheric Chemistry and Climate Model Intercomparison Project), Atmos. Chem. Phys. Discuss., 12, 21713-21778, doi:10.5194/acpd-12-21713-2012, 2012.

Li, D. and Shine, K. P.: A 4-Dimensional Ozone Climatology for UGAMP Models, UGAMP Internal Report No. 35, http://badc. nerc.ac.uk/data/ugamp-o3-climatology, April 1995.

Lin, P., Fu, Q., Solomon, S., and Wallace, J. M.: Temperature Trend Patterns in Southern Hemisphere High Latitudes: Novel Indicators of Stratospheric Change, J. Climate, 22, 6325-6340, doi:10.1175/2009JCLI2971.1, 2009.

Linvill, D. E., Hooker, W. J., and Olson, B.: Ozone in Michigan's environment 1876-1880, Mon. Weather Rev., 108, 1880-1891, 1980.

Logan, J. A.: An analysis of ozonesonde data for the troposphere: Recommendations for testing 3-D models, and development of a gridded climatology for tropospheric ozone, J. Geophys. Res., 104, 16115-16149, 1999.

Logan, J. A., Staehelin, J., Megretskaia, I. A., Cammas, J.-P., Thouret, V., Claude, H., De Backer, H., Steinbacher, M., Scheel, H.-E., Stübi, R., Fröhlich, M., and Derwent, R.: Changes in ozone over Europe: Analysis of ozone measurements from sondes, regular aircraft (MOZAIC) and alpine surface sites, J. Geophys. Res., 117, D09301, doi:10.1029/2011JD016952, 2012.

McLinden, C. A., Olsen, S. C., Hannegan, B., Wild, O., Prather, M. J., and Sundet, J.: Stratospheric ozone in 3-D models: A simple chemistry and the cross-tropopause flux, J. Geophys. Res., 105, 14653-14666, 2000.

Meinshausen, M., Smith, S. J., Calvin, K., Daniel, J. S., Kainuma, M. L. T., Lamarque, J.-F., Matsumoto, K., Montzka, S. A., Raper, S. C. B., Riahi, K., Thomson, A., Velders, G. J. M., and van Vuuren, D. P. P.: The RCP greenhouse gas concentrations and their extensions from 1765 to 2300, Climatic Change, 109, 213-241, doi:10.1007/s10584-011-0156-z, 2011.

Mickley, L. J., Jacob, D. J., and Rind, D.: Uncertainty in preindustrial abundance of tropospheric ozone: Implications for radiative forcing calculations, J. Geophys. Res., 106, 3389-3399, 2001.

Myhre, G. and Stordal, F.: Role of spatial and temporal variations in the computation of radiative forcing and GWP, J. Geophys. Res.-Atmos., 102, 11181-11200, 1997.

Myhre, G., Highwood, E. J., Shine, K. P., and Stordal, F.: New estimates of radiative forcing due to well mixed greenhouse gases, Geophys. Res. Lett., 25, 2715-2718, 1998.

Myhre, G., Shine, K. P., Rädel, G., Gauss, M., Isaksen, I. S. A., Tang, Q., Prather, M. J., Williams, J. E., van Velthoven,P., Dessens, O., Koffi, B., Szopa, S., Hoor, P., Grewe, V., BorkenKleefeld, J., Berntsen, T. K., and Fuglestvedt, J. S.: Radiative forcing due to changes in ozone and methane caused by the transport sector, Atmos. Environ., 45, 387-394, 2011.

Naik, V., Voulgarakis, A., Fiore, A. M., Horowitz, L. W., Lamarque, J.-F., Lin, M., Prather, M. J., Young, P. J., Bergmann, D., Cameron-Smith, P. J., Cionni, I., Collins, W. J., Dalsøren, S. B., Doherty, R., Eyring, V., Faluvegi, G., Folberth, G. A., Josse, B., Lee, Y. H., MacKenzie, I. A., Nagashima, T., van Noije, T. P. C., Plummer, D. A., Righi, M., Rumbold, S. T., Skeie, R., Shindell, D. T., Stevenson, D. S., Strode, S., Sudo, K., Szopa, S., and Zeng, G.: Preindustrial to present day changes in tropospheric hydroxyl radical and methane lifetime from the Atmospheric Chemistry and Climate Model Intercomparison Project (ACCMIP), Atmos. Chem. Phys. Discuss., 12, 30755-30804, doi:10.5194/acpd-1230755-2012, 2012.

Oltmans, S. J., Lefohn, A. S., Harris, J. M., Galbally, I., Scheel, H. E., Bodeker, G., Brunke, E., Claude, H., Tarasick, D., Johnson, B. J., Simmonds, P., Shadwick, D., Anlauf, K., Hayden, K., Schmidlin, F., Fujimoto, T., Akagi, K., Meyer, C., Nichol, S., Davies, J., Redondas, A., and Cuevas, E.: Long-term changes in tropospheric ozone, Atmos. Environ., 40, 3156-3173, doi:10.1016/j.atmosenv.2006.01.029, 2006.

Oltmans, S. J., Lefohn, A. S., Shadwick, D., Harris, J. M., Scheel, H. E., Galbally, I., Tarasick, D. W., Johnson, B. J., Brunke, E.-G., Claude, H., Zeng, G., Nichol, S., Schmidlin, F., Davies, J., Cuevas, E., Redondas, A., Naoe, H., Nakano, T., and Kawasato, T.: Recent tropospheric ozone changes - A pattern dominated by slow or no growth, Atmos. Environ., 67, 331-351, doi:10.1016/j.atmosenv.2012.10.057, 2013.

Parrish, D. D., Law, K. S., Staehelin, J., Derwent, R., Cooper, O. R., Tanimoto, H., Volz-Thomas, A., Gilge, S., Scheel, H.-E., Steinbacher, M., and Chan, E.: Long-term changes in lower tropospheric baseline ozone concentrations at northern mid-latitudes, Atmos. Chem. Phys., 12, 11485-11504, doi:10.5194/acp-1211485-2012, 2012.

Pavelin, E. G., Johnson, C. E., Rughooputh, S., and Toumi, R.: Evaluation of pre-industrial surface ozone measurements made using Schönbein's method, Atmos. Environ., 33, 919-929, doi:10.1016/S1352-2310(98)00257-X, 1999.

Pope, V. D., Gallani, M. L., Rowntree, P. R., and Stratton, R. A.: The impact of new physical parameterizations in the Hadley Centre climate model: HadAM3, Clim. Dyn., 16, 123-146, doi:10.1007/s003820050009, 2000.

Prather, M. J.: Time scales in atmospheric chemistry: Theory, GWPs for $\mathrm{CH} 4$ and $\mathrm{CO}$, and runaway growth, Geophys. Res. Lett., 23, 2597-2600, doi:10.1029/96GL02371, 1996. 
Prather, M. J., Ehhalt, D., Dentener, F., Derwent, R., Dlugokencky, E., Holland, E., Isaksen, I., Katima, J., Kirchoff, V., Matson, P., Midgley, P. and Wang, M.: Atmospheric chemistry and greenhouse gases, in: Climate Change 2001: The Scientific Basis. Contribution of Working Group I to the Third Assessment Report of the Intergovernmental Panel on Climate Change, Houghton, J. T., Ding, Y., Griggs, D. J., Noguer, M., van der Linden, P. J., Dai, X., Maskell, K., and Johnson, C. A., Cambridge University Press, Cambridge, UK, 329-287, 2001.

Prather, M. J., Zhu, X., Tang, Q., Hsu, J., and Neu, J. L.:An atmospheric chemist in search of the tropopause, J. Geophys. Res., 116, D04306, doi:10.1029/2010JD014939, 2011.

Prinn, R. G., Weiss, R. F., Fraser, P. J., Simmonds, P. G., Cunnold, D. M., Alyea, F. N., O’Doherty, S., Salameh, P., Miller, B. R., Huang, J., Wang, R. H. J., Hartley, D. E., Harth, C., Steele, L. P., Sturrock, G., Midgley, P. M., and McCulloch, A.: A history of chemically and radiatively important gases in air deduced from ALE/GAGE/AGAGE, J. Geophys. Res., 105, 1775117792, 2000.

Ramanathan, V. and Dickinson, R. E.: Role of stratsospheric ozone in the zonal and seasonal radiative energy balance of the Earthtroposphere system, J. Atmos. Sci., 36, 1084-1104, 1979.

Ramaswamy, V., Boucher, O., Haigh, J., Hauglustaine, D., Haywood, J., Myhre, G., Nakajima, T., Shi, G. Y., and Solomon, S.: Radiative forcing of climate change, in: Climate Change 2001: The Scientific Basis, Contribution of Working Group I to the Third Assessment Report of the Intergovernmental Panel on Climate Change, edited by: Houghton, J. T., Ding, Y., Griggs, D. J., Noguer, M., van der Linden, P. J., Dai, X., Maskell, K., and Johnson, C. A., 349-416, Cambridge Univ. Press, New York, 2001.

Ray, E. A., Moore, F. L., Rosenlof, K. H., Davis, S. M., Boenisch, H., Morgenstern, O., Smale, D., Rozanov, E., Hegglin, M., Pitari, G., Mancini, E., Braesicke, P., Butchart, N., Hardiman, S., Li, F., Shibata, K., and Plummer, D. A.: Evidence for changes in stratospheric transport and mixing over the past three decades based on multiple data sets and tropical leaky pipe analysis, J. Geophys. Res., 115, D21304, doi:10.1029/2010JD014206, 2010.

Rubin, M. B.: The History of Ozone. The Sch?nbein Period, 18391868, Bull. Hist. Chem., 26, 40-56, 2001.

Sanderson, M. G., Collins, W. J., Hemming, D. L., and Betts, R. A.: Stomatal conductance changes due to increasing carbon dioxide levels: projected impact on surface ozone levels, Tellus B, 59, 404, doi:10.1111/j.1600-0889.2007.00277.x, 2007.

Sayer, A. M., Poulsen, C. A., Arnold, C., Campmany, E., Dean, S., Ewen, G. B. L., Grainger, R. G., Lawrence, B. N., Siddans, R., Thomas, G. E., and Watts, P. D.: Global retrieval of ATSR cloud parameters and evaluation (GRAPE): dataset assessment, Atmos. Chem. Phys., 11, 3913-3936, doi:10.5194/acp-11-39132011, 2011.

Schumann, U. and Huntrieser, H.: The global lightning-induced nitrogen oxides source, Atmos. Chem. Phys., 7, 3823-3907, doi:10.5194/acp-7-3823-2007, 2007.

Shindell, D. T., Faluvegi, G., Bell, N., and Schmidt, G.: An emissions-based view of climate forcing by methane and tropospheric ozone, Geophys. Res. Lett., 32, L04803, doi:10.1029/2004GL021900, 2005.

Shindell, D. T., Faluvegi, G., Koch, D. M., Schmidt, G. A., Unger, N., and Bauer, S. E.: Improved attribution of climate forcing to emissions, Science, 326, 716-718, doi:10.1126/science.1174760, 2009.

Shindell, D. T., Lamarque, J.-F., Schulz, M., Flanner, M., Jiao, C., Chin, M., Young, P., Lee, Y. H., Rotstayn, L., Milly, G., Faluvegi, G., Balkanski, Y., Collins, W. J., Conley, A. J., Dalsoren, S., Easter, R., Ghan, S., Horowitz, L., Liu, X., Myhre, G., Nagashima, T., Naik, V., Rumbold, S., Skeie, R., Sudo, K., Szopa, S., Takemura, T., Voulgarakis, A., and Yoon, J.-H.: Radiative forcing in the ACCMIP historical and future climate simulations, Atmos. Chem. Phys. Discuss., 12, 21105-21210, doi:10.5194/acpd-12-21105-2012, 2012.

Sitch, S., Cox, P. M., Collins, W. J., and Huntingford, C.: Indirect radiative forcing of climate change through ozone effects on the land-carbon sink, Nature, 448, 791-795, doi:10.1038/nature06059, 2007.

Skeie, R. B., Berntsen, T. K., Myhre, G., Tanaka, K., Kvalevåg, M. M., and Hoyle, C. R.: Anthropogenic radiative forcing time series from pre-industrial times until 2010, Atmos. Chem. Phys., 11, 11827-11857, doi:10.5194/acp-11-11827-2011, 2011.

SPARC-CCMVal, SPARC Report on the Evaluation of ChemistryClimate Models, edited by: Eyring, V., Shepherd, T. G., and Waugh, D. W., SPARC Report No. 5, WCRP-132, WMO/TDNo. 1526, http://www.sparc-climate.org/publications/ sparc-reports/sparc-report-no5 (last access: October 2012), 2010.

Staehelin, J., Thudium, J., Buehler, R., Volz-Thomas, A., and Graber, W.: Trends in surface ozone concentrations at Arosa (Switzerland), Atmos. Environ., 28, 75-87, 1994.

Stamnes, K., Tsay, S. C., Wiscombe, W., and Jayaweera, K.: Numerically Stable Algorithm For Discrete-Ordinate-Method Radiative-Transfer In Multiple-Scattering And Emitting Layered Media, Appl. Optics, 27, 2502-2509, 1988.

Stevenson, D. S., Doherty, R. M., Sanderson, M. G., Johnson, C. E., Collins, W. J., and Derwent, R. G.: Impacts of climate change and variability on tropospheric ozone and its precursors, Faraday Discuss., 130, 41-57, doi:10.1039/b417412g, 2005.

Stevenson, D. S., Dentener, F. J., Schultz, M. G., Ellingsen, K., van Noije, T. P. C., Wild, O., Zeng, G., Amann, M., Atherton, C. S., Bell, N., Bergmann, D. J., Bey, I., Butler, T., Cofala, J., Collins, W. J., Derwent, R. G., Doherty, R. M., Drevet, J., Eskes, H. J., Fiore, A. M., Gauss, M., Hauglustaine, D. A., Horowitz, L. W., Isaksen, I. S. A., Krol, M. C., Lamarque, J.-F., Lawrence, M. G., Montanaro, V., Muller, J.-F., Pitari, G., Prather, M. J., Pyle, J. A., Rast, S., Rodriguez, J. M., Sanderson, M. G., Savage, N. H., Shindell, D. T., Strahan, S. E., Sudo, K., and Szopa, S.: Multimodel ensemble simulations of present-day and near-future tropospheric ozone, J. Geophys. Res., 111, D08301, doi:10.1029/2005JD006338, 2006.

Stohl, A., Bonasoni, P., Cristofanelli, P., Collins, W., Feichter, J., Frank, A., Forster, C., Gerasopoulos, E., Gaggeler, H., James, P., Kentarchos, T., Kromp-Kolb, H., Kruger, B., Land, C., Meloen, J., Papayannis, A., Priller, A., Seibert, P., Sprenger, M., Roelofs, G. J., Scheel, H. E., Schnabel, C., Siegmund, P., Tobler, L., Trickl, T., Wernli, H., Wirth, V., Zanis, P., and Zerefos, C.: Stratosphere-troposphere exchange: A review, and what we have learned from STACCATO, J. Geophys. Res., 108, 8516, doi:10.1029/2002JD002490, 2003.

Szopa, S, Balkanski, Y., Schulz, M., Bekki, S., Cugnet, D., FortemsCheiney, A., Turquety, S., Cozic, A., Deandreis, C., Hauglustaine, D., Idelkadi, A., Lathiere, J., Lefevre, F., Marchand, M., 
Vuolo, R., Yan, N., and Dufresne, J.-L.: Aerosol and Ozone changes as forcing for climate evolution between 1850 and 2100, Climate Dynamics, doi:10.1007/s00382-012-1408-y, 2012.

Thouret, V., Cammas, J.-P., Sauvage, B., Athier, G., Zbinden, R., Nédélec, P., Simon, P., and Karcher, F.: Tropopause referenced ozone climatology and inter-annual variability (1994-2003) from the MOZAIC programme, Atmos. Chem. Phys., 6, 1033-1051, doi:10.5194/acp-6-1033-2006, 2006.

Tian, W. and Chipperfield, M. P.: A new coupled chemistry-climate model for the stratosphere: The importance of coupling for future O3-climate predictions, Q. J. Roy. Meteorol. Soc., 131, 281-303, doi:10.1256/qj.04.05, 2005.

Tilmes, S., Lamarque, J.-F., Emmons, L. K., Conley, A., Schultz, M. G., Saunois, M., Thouret, V., Thompson, A. M., Oltmans, S. J., Johnson, B., and Tarasick, D.: Technical Note: Ozonesonde climatology between 1995 and 2011: description, evaluation and applications, Atmos. Chem. Phys., 12, 74757497, doi:10.5194/acp-12-7475-2012, 2012.

van Vuuren, D. P., Edmonds, J., Kainuma, M., Riahi, K., Thomson, A., Hibbard, K., Hurtt, G. C., Kram, T., Krey, V., Lamarque, J.F., Masui, T., Meinshausen, M., Nakicenovic, N., Smith, S. J., and Rose, S. K.: The representative concentration pathways: an overview, Climatic Change, 109, 5-31, doi:10.1007/s10584-0110148-z, 2011.

Volz, A. and Kley, D.: Evaluation of the Montsouris series of ozone measurements made in the nineteenth century, Nature, 332, 240 242, doi:10.1038/332240a0, 1988.

von Hardenberg, J., Vozella, L., Tomasi, C., Vitale, V., Lupi, A., Mazzola, M., van Noije, T. P. C., Strunk, A., and Provenzale, A.: Aerosol optical depth over the Arctic: a comparison of ECHAMHAM and TM5 with ground-based, satellite and reanalysis data, Atmos. Chem. Phys., 12, 6953-6967, doi:10.5194/acp-12-69532012, 2012.

Voulgarakis, A., Naik, V., Lamarque, J.-F., Shindell, D. T., Young, P. J., Prather, M. J., Wild, O., Field, R. D., Bergmann, D., CameronSmith, P., Cionni, I., Collins, W. J., Dalsøren, S. B., Doherty, R. M., Eyring, V., Faluvegi, G., Folberth, G. A., Horowitz, L. W., Josse, B., MacKenzie, I. A., Nagashima, T., Plummer, D. A., Righi, M., Rumbold, S. T., Stevenson, D. S., Strode, S. A., Sudo, K., Szopa, S., and Zeng, G.: Analysis of present day and future $\mathrm{OH}$ and methane lifetime in the ACCMIP simulations, Atmos. Chem. Phys., 13, 2563-2587, doi:10.5194/acp-13-25632013, 2013.

Walters, D. N., Best, M. J., Bushell, A. C., Copsey, D., Edwards, J. M., Falloon, P. D., Harris, C. M., Lock, A. P., Manners, J. C., Morcrette, C. J., Roberts, M. J., Stratton, R. A., Webster, S., Wilkinson, J. M., Willett, M. R., Boutle, I. A., Earnshaw, P. D., Hill, P. G., MacLachlan, C., Martin, G. M., Moufouma-Okia, W., Palmer, M. D., Petch, J. C., Rooney, G. G., Scaife, A. A., and Williams, K. D.: The Met Office Unified Model Global Atmosphere 3.0/3.1 and JULES Global Land 3.0/3.1 configurations, Geosci. Model Dev., 4, 919-941, doi:10.5194/gmd-4-919-2011, 2011.

Wang, Y. and Jacob, D. J.: Anthropogenic forcing on tropospheric ozone and $\mathrm{OH}$ since preindustrial times, J. Geophys. Res., 103, 31123-31135, 1998.
West, J. J., Fiore, A. M., Naik, V., Horowitz, L. W., Schwarzkopf, M. D., and Mauzerall, D. L.: Ozone air quality and radiative forcing consequences of changes in ozone precursor emissions, Geophys. Res. Lett., 34, L06806, doi:10.1029/2006GL029173, 2007.

Wilcox, L. J., Hoskins, B. J. and Shine, K. P.: A global blended tropopause based on ERA data. Part II: Trends and tropical broadening, Q. J. Roy. Meteorol. Soc., 138, 576-584, doi:10.1002/qj.910, 2012.

Wild, O., Fiore, A. M., Shindell, D. T., Doherty, R. M., Collins, W. J., Dentener, F. J., Schultz, M. G., Gong, S., MacKenzie, I. A., Zeng, G., Hess, P., Duncan, B. N., Bergmann, D. J., Szopa, S., Jonson, J. E., Keating, T. J., and Zuber, A.: Modelling future changes in surface ozone: a parameterized approach, Atmos. Chem. Phys., 12, 2037-2054, doi:10.5194/acp-12-20372012, 2012.

Wilson, R. C., Fleming, Z. L., Monks, P. S., Clain, G., Henne, S., Konovalov, I. B., Szopa, S., and Menut, L.: Have primary emission reduction measures reduced ozone across Europe? An analysis of European rural background ozone trends 1996-2005, Atmos. Chem. Phys., 12, 437-454, doi:10.5194/acp-12-437-2012, 2012.

Wolff, E. W.: Greenhouse gases in the Earth system: a palaeoclimate perspective, Philos. T. Roy. Soc. London A, 369, 21332147, 2011.

Wu, S., Mickley, L. J., Kaplan, J. O., and Jacob, D. J.: Impacts of changes in land use and land cover on atmospheric chemistry and air quality over the 21st century, Atmos. Chem. Phys., 12, 1597-1609, doi:10.5194/acp-12-1597-2012, 2012.

Young, P. J., Archibald, A. T., Bowman, K. W., Lamarque, J.-F., Naik, V., Stevenson, D. S., Tilmes, S., Voulgarakis, A., Wild, O., Bergmann, D., Cameron-Smith, P., Cionni, I., Collins, W. J., Dalsøren, S. B., Doherty, R. M., Eyring, V., Faluvegi, G., Horowitz, L. W., Josse, B., Lee, Y. H., MacKenzie, I. A., Nagashima, T., Plummer, D. A., Righi, M., Rumbold, S. T., Skeie, R. B., Shindell, D. T., Strode, S. A., Sudo, K., Szopa, S., and Zeng, G.: Pre-industrial to end 21st century projections of tropospheric ozone from the Atmospheric Chemistry and Climate Model Intercomparison Project (ACCMIP), Atmos. Chem. Phys., 13, 2063-2090, doi:10.5194/acp-13-2063-2013, 2013.

Young, P. J., Rosenlof, K. H., Solomon, S., Sherwood, S. C., Fu, Q., and Lamarque, J.-F.: Changes in Stratospheric Temperatures and Their Implications for Changes in the BrewerDobson Circulation, 1979-2005, J. Clim., 25, 1759-1772, doi:10.1175/2011JCLI4048.1, 2012.

Zeng, G. and Pyle, J. A.: Changes in tropospheric ozone between 2000 and 2100 modeled in a chemistry-climate model, Geophys. Res. Lett., 30, 1392, doi:10.1029/2002GL016708, 2003.

Zeng, G., Morgenstern, O., Braesicke, P., and Pyle, J. A.: Impact of stratospheric ozone recovery on tropospheric ozone and its budget, Geophys. Res. Lett., 37, L09805, doi:10.1029/2010GL042812, 2010.

Zhong, W., Osprey, S. M., Gray, L. J., and Haigh, J. D.: Influence of the prescribed solar spectrum on calculations of atmospheric temperature, Geophys. Res. Lett., 35, L22813, doi:10.1029/2008GL035993, 2008. 